\title{
Source apportionment of organic aerosol from 2-year highly time-resolved measurements by an aerosol chemical speciation monitor in Beijing, China
}

\author{
Yele Sun ${ }^{1,2,3}$, Weiqi Xu ${ }^{1,3}$, Qi Zhang ${ }^{4}$, Qi Jiang ${ }^{1, a}$, Francesco Canonaco ${ }^{5}$, André S. H. Prévôt ${ }^{5}$, Pingqing Fu ${ }^{1,2,3}$, \\ Jie Li $^{1}$, John Jayne ${ }^{6}$, Douglas R. Worsnop ${ }^{6}$, and Zifa Wang ${ }^{1,2,3}$ \\ ${ }^{1}$ State Key Laboratory of Atmospheric Boundary Layer Physics and Atmospheric Chemistry, Institute of Atmospheric \\ Physics, Chinese Academy of Sciences, Beijing 100029, China \\ ${ }^{2}$ Center for Excellence in Regional Atmospheric Environment, Institute of Urban Environment, Chinese Academy of \\ Sciences, Xiamen 361021, China \\ ${ }^{3}$ University of Chinese Academy of Sciences, Beijing 100049, China \\ ${ }^{4}$ Department of Environmental Toxicology, University of California, 1 Shields Ave., Davis, CA 95616, USA \\ ${ }^{5}$ Laboratory of Atmospheric Chemistry, Paul Scherrer Institute, Villigen PSI 5232, Switzerland \\ ${ }^{6}$ Aerodyne Research, Inc., Billerica, MA 01821, USA \\ ${ }^{a}$ now at: National Meteorological Centre, Beijing 100081, China
}

Correspondence: Yele Sun (sunyele@mail.iap.ac.cn)

Received: 17 December 2017 - Discussion started: 2 January 2018

Revised: 27 April 2018 - Accepted: 25 May 2018 - Published: 18 June 2018

\begin{abstract}
Organic aerosol (OA) represents a large fraction of submicron aerosols in the megacity of Beijing, yet longterm characterization of its sources and variations is very limited. Here we present an analysis of in situ measurements of $\mathrm{OA}$ in submicrometer particles with an aerosol chemical speciation monitor (ACSM) for 2 years from July 2011 to May 2013. The sources of OA are analyzed with a multilinear engine (ME-2) by constraining three primary OA factors including fossil-fuel-related OA (FFOA), cooking OA (COA), and biomass burning OA (BBOA). Two secondary OAs (SOA), representing a less oxidized oxygenated OA (LO-OOA) and a more oxidized (MO-OOA), are identified during all seasons. The monthly average concentration OA varied from 13.6 to $46.7 \mu \mathrm{g} \mathrm{m}^{-3}$ with a strong seasonal pattern that is usually highest in winter and lowest in summer. FFOA and BBOA show similarly pronounced seasonal variations with much higher concentrations and contributions in winter due to enhanced coal combustion and biomass burning emissions. The contribution of COA to OA, however, is relatively stable (10-15\%) across different seasons, yet presents significantly higher values at low relative humidity levels $(\mathrm{RH}<30 \%)$, highlighting the important role of COA during clean periods. The two SOA factors present very dif-
\end{abstract}

ferent seasonal variations. The pronounced enhancement of LO-OOA concentrations in winter indicates that emissions from combustion-related primary emissions could be a considerable source of SOA under low-temperature $(T)$ conditions. Comparatively, MO-OOA shows high concentrations consistently at high RH levels across different $T$ levels, and the contribution of MO-OOA to OA is different seasonally with lower values occurring more in winter (30-34\%) than other seasons (47-64\%). Overall, SOA (= LO-OOA + MOOOA) dominates OA composition during all seasons by contributing $52-64 \%$ of the total OA mass in the heating season and $65-75 \%$ in non-heating seasons. The variations in OA composition as a function of OA mass loading further illustrate the dominant role of SOA in OA across different mass loading scenarios during all seasons. However, we also observed a large increase in FFOA associated with a corresponding decrease in MO-OOA during periods with high OA mass loadings in the heating season, illustrating an enhanced role of coal combustion emissions during highly polluted episodes. Potential source contribution function analysis further shows that the transport from the regions located to the south and southwest of Beijing within $\sim 250 \mathrm{~km}$ can 
contribute substantially to high FFOA and BBOA concentrations in the heating season.

\section{Introduction}

Organic aerosol (OA) is ubiquitous in the atmosphere and constitutes a large fraction of submicron aerosol worldwide (Zhang et al., 2007; Jimenez et al., 2009). Organic aerosol has two different sources. One is direct emissions from combustion processes (e.g., burning of fossil fuel and biomass), which is known as primary organic aerosol (POA). The other is secondary formation from the oxidation of volatile organic compounds (VOCs) termed secondary organic aerosol (SOA) (Hallquist et al., 2009). Recent studies have found that SOA is the major component of OA not only in rural and remote regions but also in the highly polluted urban regions (Zhang et al., 2007; Jimenez et al., 2009). Although model simulations of SOA have been improved during the last decade contributing to significant improvements in understanding the formation mechanisms and volatility of OA, the discrepancy between model simulations and ambient observations can still be substantial (Shrivastava et al., 2011; Fu et al., 2012; Fast et al., 2014). As a result, SOA contributes one of the largest uncertainties in evaluating climate radiation forcing of aerosol particles (Boucher et al., 2013). While a better understanding of SOA formation and evolutionary mechanisms is essential to improve model performances (Shrivastava et al., 2017), constraining the models with observations, particularly long-term measurements would be one of the most effective ways to reduce the radiative forcing uncertainties.

Aerodyne aerosol mass spectrometer (Jayne et al., 2000; Canagaratna et al., 2007) is one of the state-of-the-art instruments by providing quantitive measurement of organic aerosol in real time. Subsequent analysis of OA mass spectra using receptor models, e.g., multiple component analysis (Zhang et al., 2005), positive matrix factorization (PMF; Ulbrich et al., 2009) and a multilinear engine (Canonaco et al., 2013) can further resolve various OA factors that correspond to different sources and processes. Since 2006, aerosol mass spectrometer (AMS) has been widely deployed in various regions in China for real-time characterization of nonrefractory submicron aerosol (NR-PM P $_{1}$ species ( $\mathrm{Li}$ et al., 2017b, and references therein). The sources of OA in different seasons were analyzed using PMF. While hydrocarbonlike OA (HOA) and oxygenated OA (OOA) are ubiquitously identified, cooking OA (COA) in urban areas, biomass burning OA (BBOA) and coal combustion OA (CCOA) in specific seasons are also resolved. PMF analysis of highresolution OA mass spectra can further differentiate between different types of SOA, for instance, less oxidized OOA (LOOOA) and more oxygenated OOA (MO-OOA). However, most of these studies are focused on intensive measurements in relatively short periods (e.g., 1-2 months) in a single season (mostly in either summer or winter), long-term measurements and characterization of OA in China are still rather limited. Zhang et al. (2013) reported the season variations in NR-PM 1 species in Beijing in 2008. The results showed the dominance of OA during all seasons. Similar conclusions were also found from the high-resolution AMS (HRAMS) measurements from 2012 to 2013 in Beijing (Hu et al., 2017). While both studies showed the dominant role of OOA in summer, the contribution of POA was quite different (76 vs. $50 \%$ ). However, most measurements in these two studies lasted approximately 1 month in each season, and our understanding of the sources and variations in OA is far from complete, particularly in a city with frequent changes in different air masses and largely different emissions sources (Guo et al., 2014; Sun et al., 2015; Zheng et al., 2016). Sun et al. (2015) conducted 1-year real-time measurements of NR-PM ${ }_{1}$ species from 2011 to 2012 using an aerosol chemical speciation monitor (ACSM). While OA showed a similar seasonal variation to those in Zhang et al. (2013) and Hu et al. (2017), substantial differences in monthly averaged mass concentrations were also observed, highlighting the importance of continuous real-time measurements for understanding seasonal characteristics. However, Sun et al. (2015) only present the characterization of the total OA; the sources and seasonal variations in different $\mathrm{OA}$ factors remain less understood.

In this work, we present an analysis of OA measurements lasting nearly 2 years by an ACSM in the megacity of Beijing. Although year-round measurements of NR$\mathrm{PM}_{1}$ species and source characterization of $\mathrm{OA}$ have been reported at many sites throughout the globe (Minguillón et al., 2015; Parworth et al., 2015; Petit et al., 2015; Ripoll et al., 2015; Bressi et al., 2016; Schlag et al., 2016; Rattanavaraha et al., 2017), real-time source characterization of OA in Beijing for more than 1 year is never reported. Here the sources of OA in each season are determined by the bilinear model with a multilinear engine (ME-2) (Paatero, 1999). The seasonal variations, diurnal cycles, and relative humidity and temperature dependence of OA source factors are elucidated. The roles of different OA factors and POA and SOA in haze pollution are discussed, and the potential source regions are also investigated with potential source contribution function analysis. To our knowledge, this study presents the longest continuous characterization of OA in Beijing, which is of great importance for validating and constraining the chemical transport models.

\section{Experimental methods}

\subsection{Sampling}

An Aerodyne aerosol chemical speciation monitor ( $\mathrm{Ng}$ et al., 2011b) was deployed at an urban site, the tower site of the Institute of Atmospheric Physics $\left(39^{\circ} 58^{\prime} \mathrm{N}, 116^{\circ} 22^{\prime} \mathrm{E}\right.$; 
49 ma.s.l.), in Beijing for long-term real-time measurements of NR-PM ${ }_{1}$ species including organics (Org), sulfate $\left(\mathrm{SO}_{4}\right)$, nitrate $\left.\mathrm{NO}_{3}\right)$, ammonium $\left(\mathrm{NH}_{4}\right)$, and chloride $(\mathrm{Chl})$. The measurements were conducted for nearly 2 years from July 2011 to May 2013 with a time resolution of approximately 15 min. In addition, gaseous species of $\mathrm{NO}_{\mathrm{y}}, \mathrm{NO}$, and $\mathrm{O}_{3}$ were simultaneously measured with a suite of gas analyzers during the same period, while $\mathrm{CO}$ and $\mathrm{SO}_{2}$ were measured during the period of December 2011-May 2013. Black carbon (BC), light extinction of dry particles at $630 \mathrm{~nm}$, and gaseous $\mathrm{NO}_{2}$ were also measured from August 2012 to May 2013 using an aethalometer (AE22, Magee Scientific), a cavity attenuated phase shift (CAPS) extinction monitor, and a CAPS $\mathrm{NO}_{2}$ monitor (Kebabian et al., 2008), respectively. The meteorological parameters, temperature $(T)$, and relative humidity $(\mathrm{RH})$ at the ground site and wind direction (WD) and wind speed (WS) at $240 \mathrm{~m}$ were obtained from the measurements at the Beijing $325 \mathrm{~m}$ meteorological tower. More detailed descriptions of the sampling site, the operations of the ACSM, and the collocated measurements are given elsewhere (Sun et al., 2012, 2015; Ge et al., 2013; Wang et al., 2015). All data in this study are reported in Beijing local time.

\subsection{Data analysis}

The ACSM data were analyzed using the standard software (v.1.5.3.0) written in Igor Pro (WaveMetrics, Inc., Oregon USA). The mass concentrations of NR-PM 1 species and the mass spectra of OA $(\mathrm{m} / \mathrm{z}, 12-140)$ were determined using a composition-dependent collection efficiency recommended by Middlebrook et al. (2012) and default relative ionization efficiencies (RIEs) were used, except for ammonium whose RIE was determined from measurements of pure ammonium nitrate. More detailed evaluations on the mass quantifications are given elsewhere (Sun et al., 2012, 2013b).

Positive matrix factorization was first performed for the ACSM OA mass spectra $(m / z 12-120)$ in each season. The detailed procedures for pretreatment of data and error matrices have been given in Ng et al. (2011b) and Sun et al. (2012). As shown in Fig. S1 in the Supplement, two factors, i.e., a hydrocarbon-like OA (HOA) and an oxygenated OA (OOA), can be relatively well resolved during all seasons. Although extending the PMF solution to more factors can help to reduce uncertainties in the separation of POA and SOA, e.g., four factors in winter 2011-2012 (Sun et al., 2013b), this often generates unrealistic factors due to the low sensitivity, low mass resolution, and limited $m / z$ values of the ACSM measurements. Moreover, it is very challenging for PMFACSM to separate BBOA from other POA factors, trafficrelated HOA from $\mathrm{COA}$ in summer, and different types of SOA in winter according to our previous studies (Sun et al., 2012, 2013b; Zhang et al., 2016). Therefore, using the prior known source information as constraints, the multilinear en- gine algorithm (ME-2) (Paatero, 1999) was used for source apportionment of OA.

In this work, the $a$-value approach was used for ME-2 analysis (Canonaco et al., 2013). The mass spectral profiles of three primary OA factors, i.e., standard HOA and BBOA from $\mathrm{Ng}$ et al. (2011a) and COA from Sun et al. (2016b), were constrained by varying a-values from 0 to 1 , while the other factors were left free. ME-2 analysis was first performed to the entire dataset assuming that all OA factors have similar spectral profiles in different seasons. Such an assumption could introduce large uncertainties for secondary aerosol factors considering the large differences in meteorological conditions and precursors of VOCs in different seasons. We then performed ME-2 analysis on the seasonal datasets of ACSM, which include summer 2011 (S11), fall 2011 (F11), winter 2011 (W11), spring 2012 (Sp12), summer 2012 (S12), fall 2012 (F12), winter 2012 (W12), and spring 2013 (Sp13). Indeed, the mass spectral profiles of LOOOA from the seasonal ME2-ACSM analysis show large differences in different seasons (Fig. 1). Therefore, the results from the seasonal ME2-ACSM analysis are used for the discussions. To better compare the variations in primary and secondary $\mathrm{OA}$ in different seasons and to also allow for some degrees of freedom for model runs, the five-factor solution, i.e., fossil-fuel-related OA (FFOA), COA, BBOA, and a less oxidized OOA (LO-OOA) and a more oxidized OOA (MO-OOA), from the average of three model runs with a-values of $0,0.1$, and 0.2 were selected. The ME- 2 results with an a-value of 0.2 are also presented for comparisons. It should be noted that the traffic-related HOA shows a remarkably similar spectral pattern as CCOA at $m / z<120$ (Sun et al., 2016b), which cannot be separated with PMFACSM. Therefore, FFOA here represents a combined factor of traffic-related HOA and CCOA. We also noticed that the diurnal cycle of FFOA showed similar pronounced mealtime peaks as that of COA in summer although these two factors were forced to separate in the ME-2 analysis. To better understand the uncertainties in quantification of FFOA and $\mathrm{COA}$, we estimated COA concentrations using $\mathrm{BC}$ as a tracer for the traffic-related FFOA in August 2012. Indeed, POA from the two-factor solution of PMF-ACSM was highly correlated $\left(r^{2}>0.75\right)$ with BC between 04:00 and 10:00 LT when cooking emissions are small, suggesting the dominant contribution of traffic emissions on $\mathrm{BC}$. The average ratio of POA / BC during this period of time (0.96) was then used to derive the traffic-related FFOA, and COA was estimated as the difference between POA and FFOA. Our results showed that COA estimated using the BC-tracer method contributed $13 \%$, on average, to OA in August, which agrees well with the ME-2 analysis (Table 1), while the value of FFOA (12\%) was lower than the sum of FFOA and BBOA (17\%). These results together suggest that the results of the $\mathrm{ME}$ analysis are quite reasonable even in summer when FFOA and COA are difficult to separate. 

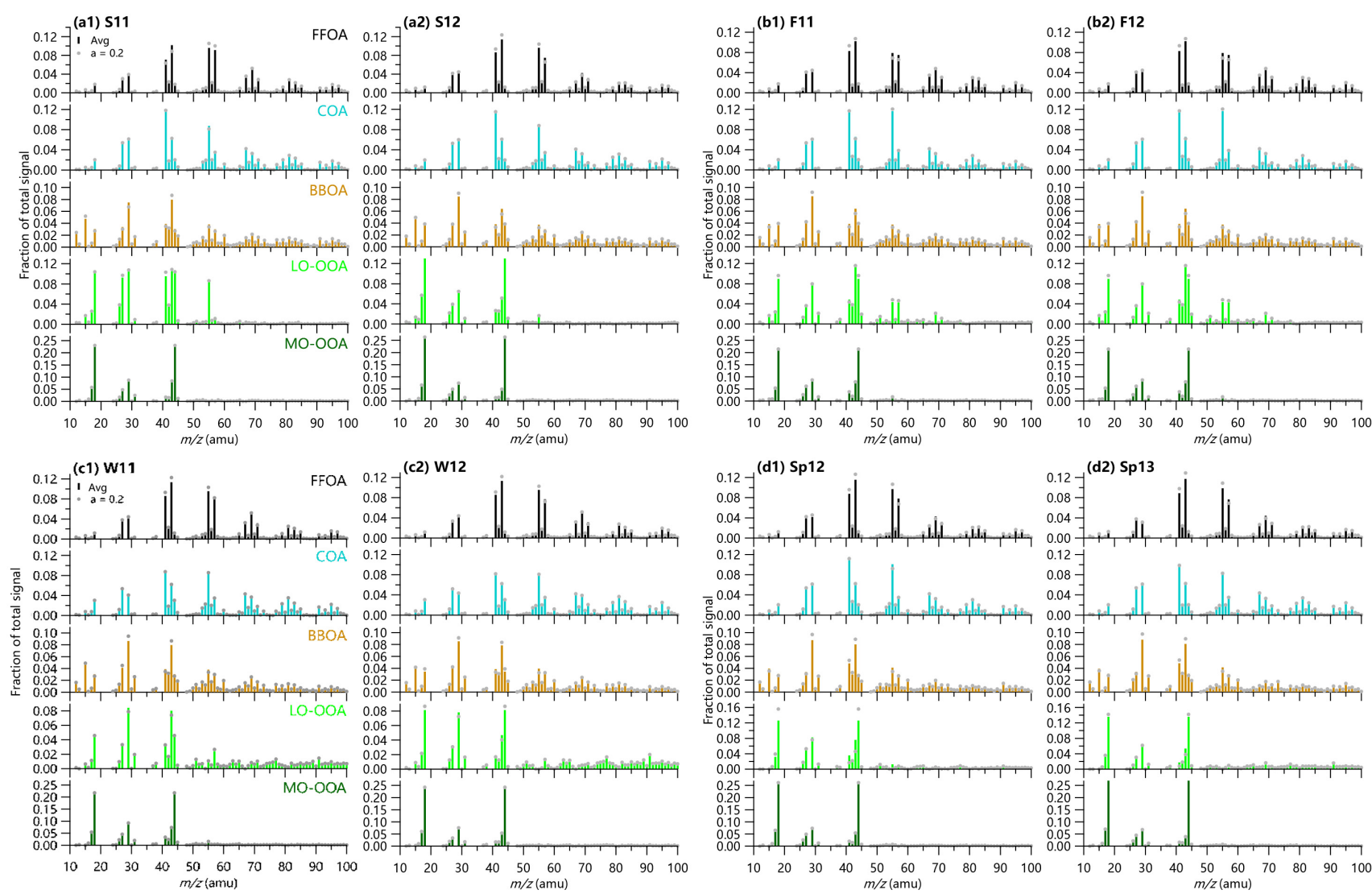

Figure 1. Mass spectral profiles of five OA factors from ME2-ACSM analysis in (a1) S11, summer 2011, (a2) S12, summer 2012; (b1) F11, fall 2011; (b2) F12, fall 2012; (c1) W11, winter 2011; (c2) W12, winter 2012; (d1) Sp12, spring 2012; and (d2) Sp13, spring 2013.

Figures S2 and S3 show a comparison of source apportionment results from three different approaches. While the monthly average SOA $(=\mathrm{LO}-\mathrm{OOA}+\mathrm{MO}-\mathrm{OOA})$ and POA $(=\mathrm{HOA}+\mathrm{COA}+\mathrm{BBOA})$ are highly correlated $\left(r^{2}=0.76\right.$ and 0.89, respectively; Fig. S3), the seasonal ME2-ACSM analysis reports an overall $16 \%$ higher SOA concentrations than the conventional PMF-ACSM analysis. The largest differences occur mainly in cold season, for example November-March, which can be partially explained by the changes in LO-OOA. Comparatively, the contributions of POA and SOA are close in warm season, for example July-October. We also compared the results between the seasonal and entire dataset from ME-2 analysis. As shown in Fig. S2, the POA and SOA contributions present differences of $5-14 \%$ on average during the first 8 months, while they are very consistent during the other months with the differences of less than $3 \%$. Figure S4 presents a comparison of POA and SOA contributions from ME2-ACSM in this study with those reported previously from PMF-ACSM (Sun et al., 2012, 2013b, 2014; Jiang et al., 2013, 2015). The results are overall consistent except for winter 2011-2012, which shows a higher SOA contribution (54\%) in this study than that $(31 \%)$ reported in Sun et al. (2013b). We found that such a difference was mainly caused by the contribution of LO-OOA (23.6\%), which was not resolved in the Sun et al. (2013b) study with PMF-ACSM.

\subsection{Potential source contribution function analysis}

The potential source regions of five OA factors in each season were determined using potential source contribution function (PSCF) analysis (Polissar, 1999) with $72 \mathrm{~h}$ back trajectories that were calculated hourly using the HYSPLIT model (Draxler and Rolph, 2013) at a releasing height of $100 \mathrm{~m}$. The back trajectories are counted in gridded cells $(i, j)$, and the PSCF is calculated as the ratio of the number of points above a threshold value (75th percentile in this study, $m_{i j}$ ) to the total points $\left(n_{i j}\right)$ in each grid cell. A weighting function that is the same as Sun et al. (2015) was further applied to the calculation to downweight cells associated with low values of $n_{i j}$. The regions with high PSCF values indicate the potential sources for high concentrations of OA factors. 


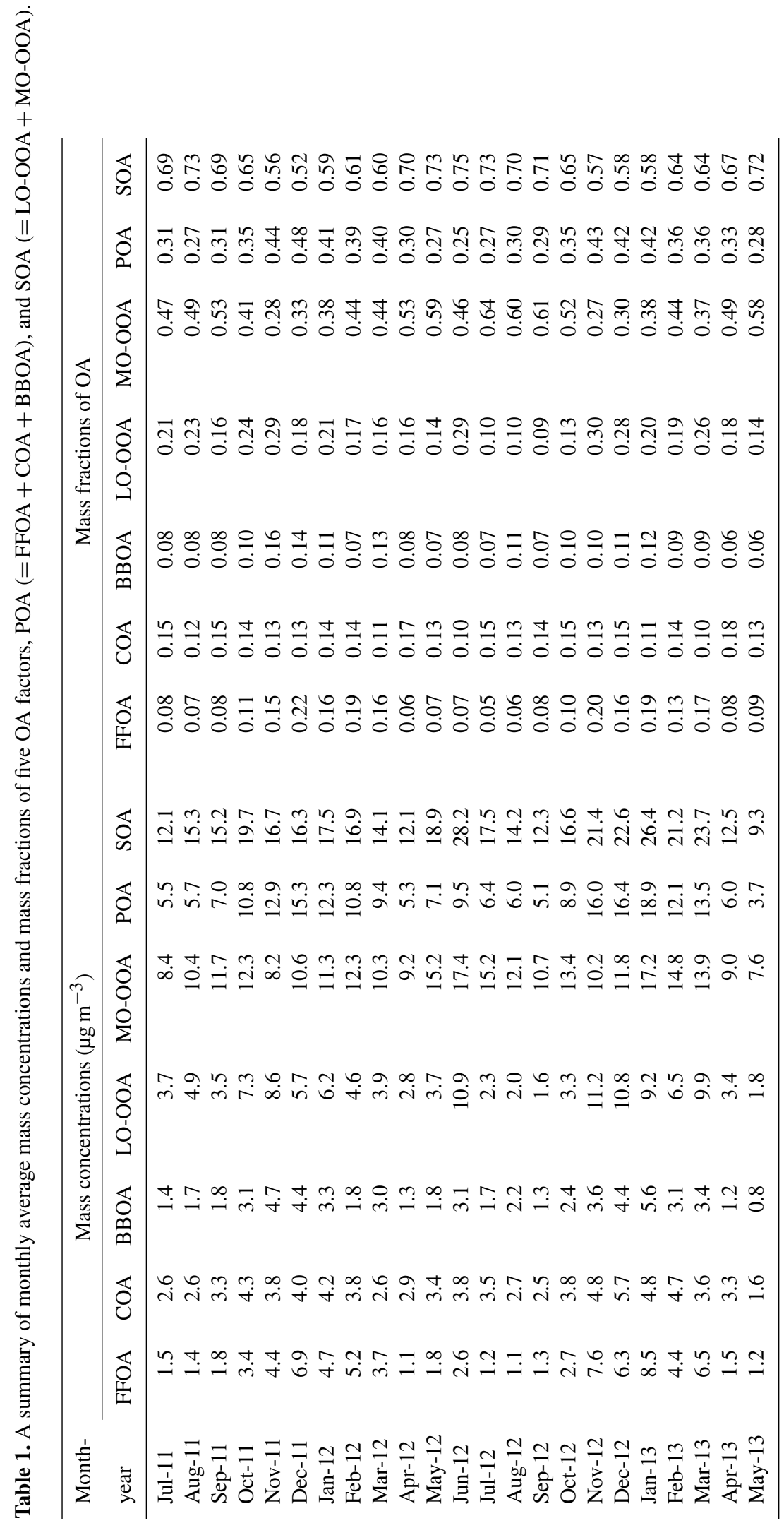




\section{Results and discussion}

\subsection{Mass concentrations, composition, and seasonal variations}

Figure 2 shows the time series of organics, five OA factors, and meteorological parameters for the entire study. OA presents dynamic variations during all seasons with hourly average concentrations ranging from 0.45 to $301 \mathrm{~g} \mathrm{~m}^{-3}$ and daily average values from 3.0 to $120 \mu \mathrm{g} \mathrm{m}^{-3}$. The variations in OA are much larger in the heating season than in summertime, mainly due to the more frequent changes between clean periods and polluted episodes (Sun et al., 2013b, 2015). Indeed, our previous studies showed a much higher frequency of clean periods $\left(\mathrm{NR}-\mathrm{PM}_{1}<10 \mu \mathrm{g} \mathrm{m}^{-3}\right)$ in winter than summer ( 23 vs. $5 \%$ ) (Sun et al., 2015). As shown in Fig. 3, OA presents a strong seasonal variation with monthly average concentrations ranging from 13.6 to $46.7 \mu \mathrm{g} \mathrm{m}^{-3}$. The concentrations in wintertime are nearly twice those in summertime mainly due to the largely enhanced coal combustion emissions in the heating season (Sun et al., 2015), and the highest concentration occurred in January 2013, a month with severe haze pollution (Sun et al., 2014; Wang et al., 2014). High OA concentration (monthly average of $37.2 \mu \mathrm{g} \mathrm{m}^{-3}$ ) was also observed in June 2012, mainly due to the impacts of agricultural burning.

Five OA factors vary differently across different seasons. FFOA that is mainly associated with traffic and coal combustion emissions presents the strongest seasonal variation among the OA factors. The monthly average FFOA concentrations are 3.7-6.9 and 4.4-8.5 $\mathrm{\mu g} \mathrm{m}^{-3}$ in the heating seasons of 2011-2012 and 2012-2013, respectively, which are much higher than 1.1-1.5 $\mu \mathrm{g} \mathrm{m}^{-3}$ in summer (Fig. 4a). Consistently, the contribution of FFOA to OA is significantly increased from $5-8 \%$ in summer to $13-22 \%$ in the heating season (Fig. 3). The time series of FFOA (Fig. 2d) also shows a substantial increase after the heating season starts on 15 November in both 2011 and 2012, supporting the large impacts of coal combustion emissions on FFOA. Comparatively, FFOA in summer is expected to be mainly from traffic emissions considering that residential coal combustion emissions could not be significant. Assuming that traffic-related FFOA is relatively constant throughout the year, we then estimate an upper limit of $\sim 70 \%$ of FFOA from coal combustion emissions in the heating season $(\sim 30 \%$ from traffic emissions). This result is consistent with our previous HRAMS analysis in winter according to which HOA and CCOA contributed 10 and $20 \%$, on average, to OA, respectively (Sun et al., 2016b).

The temporal variations in COA are characterized by pronounced daily peaks that are associated with cooking emissions (Fig. 2e). However, the seasonal difference of COA is much smaller than that of FFOA, for example, the COA concentration is $3.8-4.2 \mu \mathrm{g} \mathrm{m}^{-3}$ in winter $2011-2012$, which is only $\sim 50-60 \%$ higher than that in summer 2011 (Fig. 4b).
This is overall consistent with the facts that cooking emissions are expected to be relatively constant throughout the year. The seasonal differences in COA concentrations can be explained by the different mixing layer heights (MLH) in different seasons, for example, a $\sim 40 \%$ higher MLH during daytime in summer than winter (Tang et al., 2016). Despite the seasonal concentration differences, the contributions of COA to OA are relatively stable, varying from 10 to $15 \%$ except for slightly higher values in April (17-18\%). These results indicate that COA is an important source of OA during all seasons, consistent with previous results observed in Beijing (Huang et al., 2010; Elser et al., 2016; Hu et al., 2016). In fact, the contributions of COA to OA are higher than those of FFOA by 3-10\% in non-heating seasons, indicating that cooking emission is a more important primary source than traffic emissions in non-heating seasons in the megacity of Beijing.

BBOA shows a similarly pronounced seasonal variation to FFOA. As shown in Fig. 4c, the BBOA concentration increases gradually from summer $\left(<\sim 2 \mu \mathrm{g} \mathrm{m}^{-3}\right)$ to winter (mostly $>4 \mu \mathrm{g} \mathrm{m}^{-3}$ ) with an enhancement by a factor of more than 2. Consistently, the contribution of BBOA to OA shows an increase from $7-8 \%$ in summer to $11-14 \%$ in winter (Fig. 3). These results indicate that BBOA is a more important source of OA in winter than summer, which is overall consistent with the fact that biomass is also an important fuel for residential heating in northern China (Chen et al., 2017). However, we also observed high BBOA concentrations in June and October, 2 months with significant impacts from agricultural burning. Our subsequent measurements in June 2013 at a suburban site, Xianghe, which is approximately $50 \mathrm{~km}$ southeast of Beijing, further support the significant agricultural burning impacts on $\mathrm{OA}$, and the contribution of BBOA was increased from 11 to $21 \%$ during the periods with biomass burning (Sun et al., 2016c). However, compared with winter, the biomass burning (BB) impacts in June and October are relatively short and usually last only a few days.

LO-OOA also presents a pronounced seasonal variation pattern, yet the highest concentration occurs in the heating season (Fig. 4d). This is not expected as the photochemical processing is more significant in summer. As indicated in Fig. 1, the mass spectral profiles of LO-OOA have many differences in different seasons in terms of $m / z 43 / 44$ ratios and the fractions of large $m / z$ values. For example, the LO-OOA spectrum in winter presents much higher signals at $m / z>60$, and the time series of LO-OOA is even correlated with primary aerosol species, e.g., FFOA $\left(r^{2}=0.58\right.$ $0.75)$, BC $\left(r^{2}=0.73\right)$, and Chl $\left(r^{2}=0.58-0.65\right)$ (Fig. S5). LO-OOA is also correlated with FFOA and Chl in spring and fall seasons, and high concentrations mainly occur during the periods with residential heating, i.e., 15-30 November and 1-15 March. These results suggest that LO-OOA in the heating season is more like a combustion-related SOA that is formed under low temperature. Another possibility is 


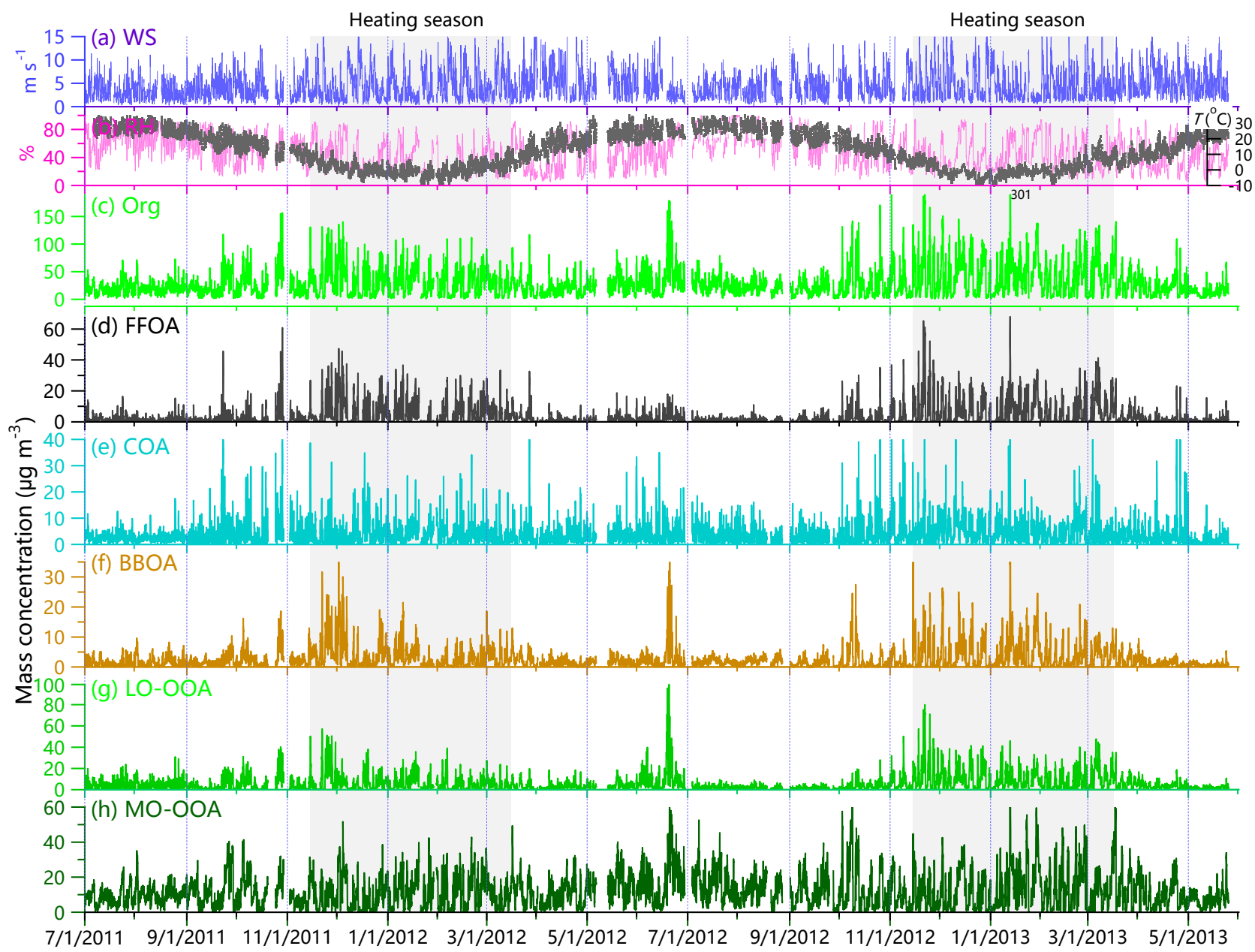

Figure 2. Time series of meteorological parameters (a) WS and (b) RH and $T$ and hourly average mass concentrations of (c) organics (Org), and (d-h) five OA factors, i.e., FFOA, COA, BBOA, LO-OOA, and MO-OOA. The period of heating season (15 November-15 March) is also marked as shaded areas.

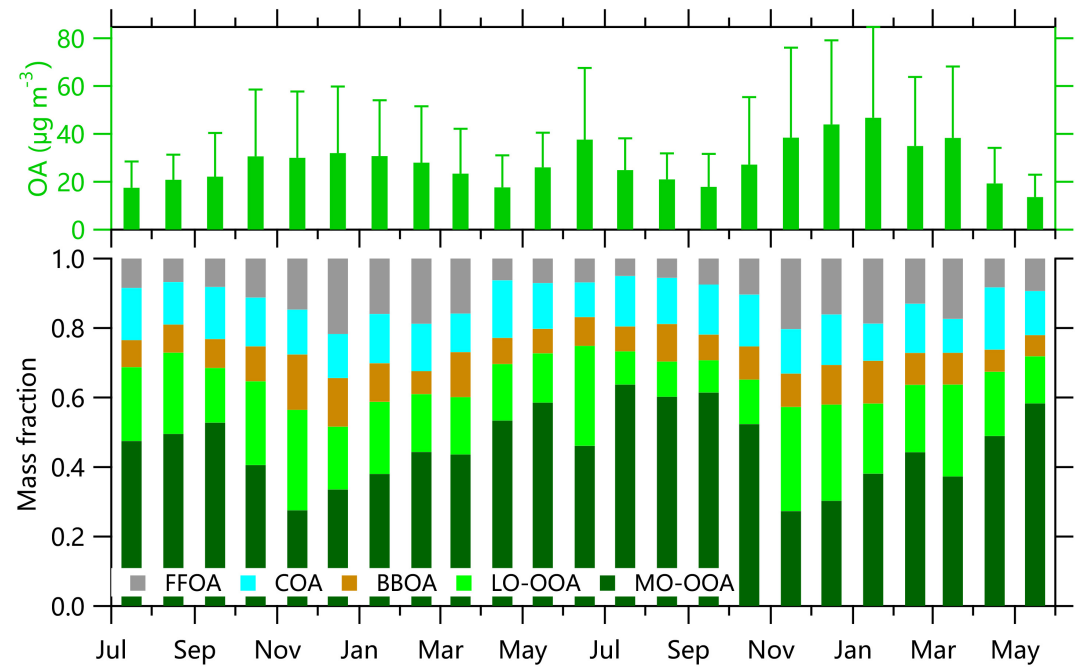

Figure 3. Monthly average OA mass concentrations and composition. The error bars represent 1 standard deviations of monthly averages. 


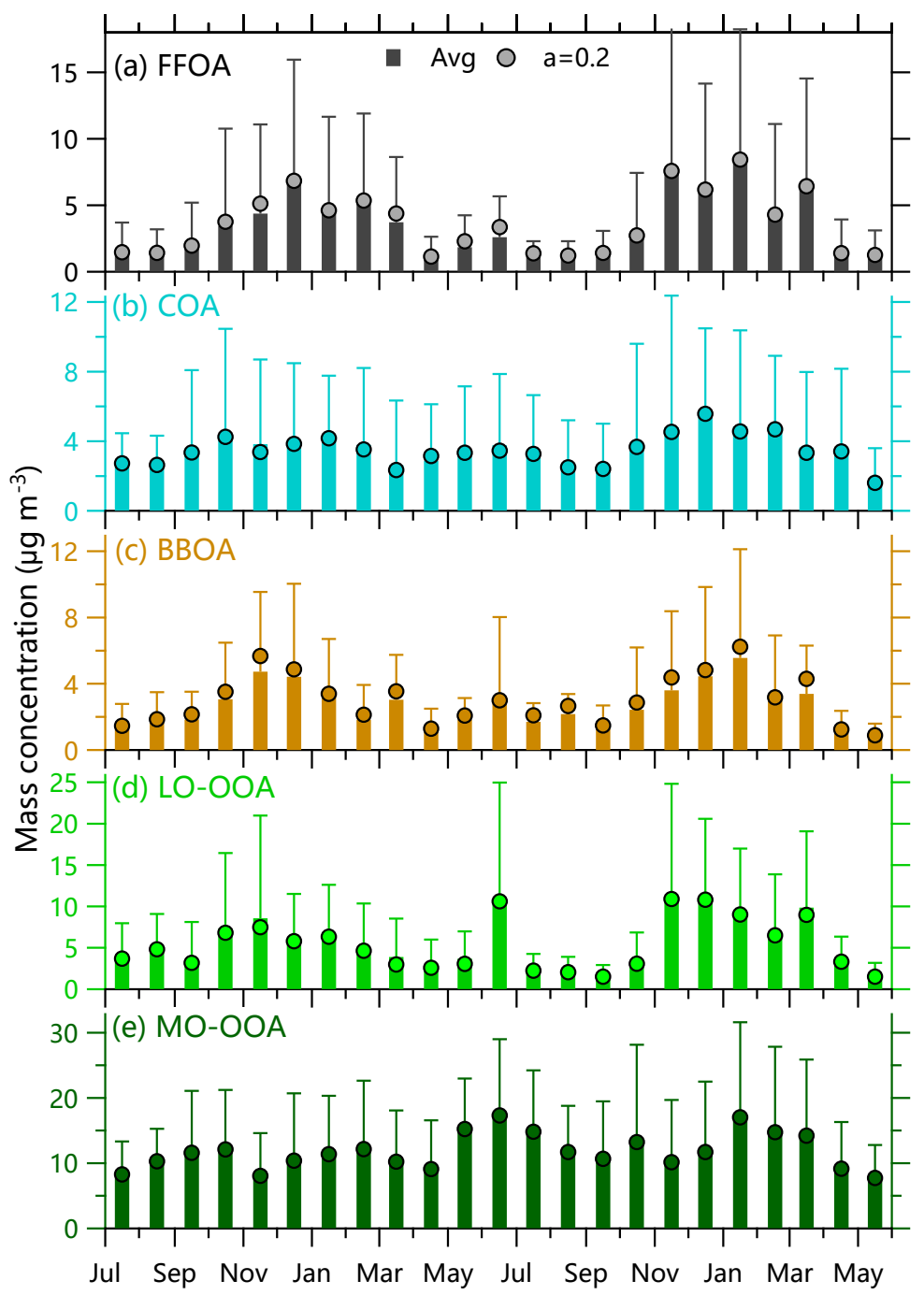

Figure 4. Monthly average mass concentrations of five OA factors. The bars are the average of ME-2 results from three model runs, i.e., $a=0,0.1$, and 0.2 . The results with $a=0.2$ are also shown for a comparison. The error bars represent 1 standard deviations of monthly averages.

that LO-OOA is still mixed with part of primary coal combustion OA, yet cannot be completely separated using the standard traffic-related HOA spectrum as a constrain. For example, previous HR-AMS studies in Beijing showed higher signals of large $m / z$ values in CCOA than HOA (Hu et al., 2016; Sun et al., 2016b). In comparison, LO-OOA is weakly correlated with other species in summer, supporting its different characteristics in winter. Note that LO-OOA shows high concentrations during late June 2012 when there are significant biomass burning impacts, and the LO-OOA spectrum is remarkably similar to that of oxygenated OA influenced by biomass burning (OOA-BB) observed in Nanjing during harvest seasons (Zhang et al., 2015). These results suggest that a larger fraction of LO-OOA in June is likely from the oxidized BBOA. Indeed, a recent study of transported wild- fire plumes showed that BBOA becomes significantly oxidized through atmospheric aging and that the mass spectra of aged BBOA can appear highly similar to low-volatility OOA (LV-OOA) (Zhou et al., 2017). In addition, our previous studies at the suburban site (Xianghe) near Beijing also found that biomass burning aerosols can be rapidly oxidized to form a considerable fraction of LO-OOA (Sun et al., 2016c). LO-OOA represents a large fraction of OA, on average accounting for 16-29 and 19-30\% in the heating seasons of 2011-2012 and 2012-2013, respectively, and also as much as $\sim 15-20 \%$ during other seasons except for the summer of $2012(\sim 10 \%)$.

The monthly average concentration of MO-OOA varies from 7.6 to $17.2 \mu \mathrm{g} \mathrm{m}^{-3}$ and does not present a strong seasonal variation in the 2 years (Fig. 4e). Also, the 

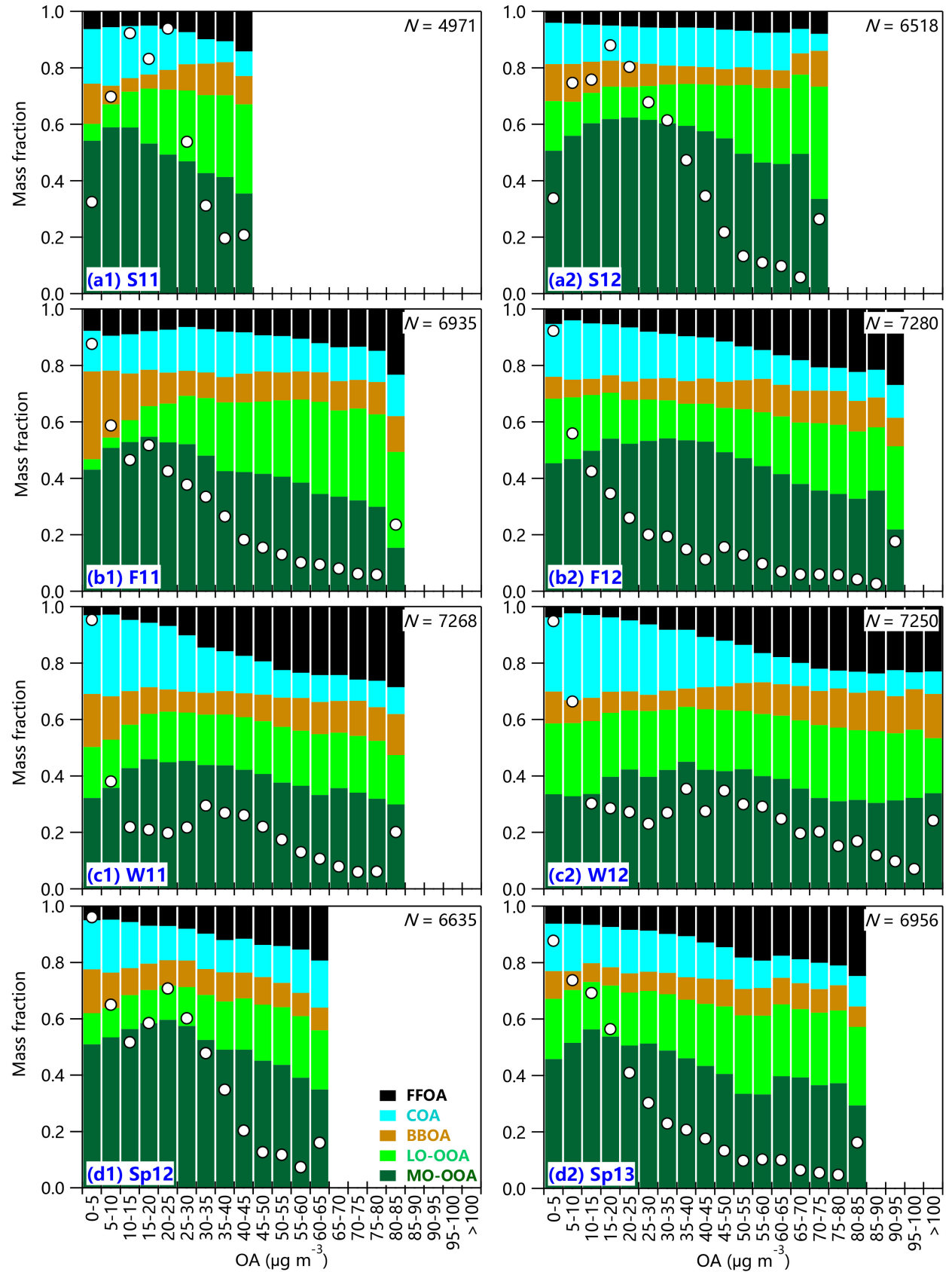

Figure 5. variations in OA composition as a function of OA mass loadings during four seasons. The data are grouped in $\mathrm{OA}$ bins $\left(5 \mu \mathrm{g} \mathrm{m}^{-3}\right.$ increment). The white circles indicate the frequency of each OA bin, and the total number of points $(N)$ for each season is also shown.

highest concentrations of MO-OOA occur in different months in different years, for example, May-July in 2012 $\left(15.2-17.4 \mu \mathrm{g} \mathrm{m}^{-3}\right)$ and January-March in 2013 (13.9$17.2 \mu \mathrm{g} \mathrm{m}^{-3}$ ). MO-OOA is tightly correlated with secondary inorganic aerosol species including nitrate, sulfate, and ammonium during all seasons $\left(r^{2}>0.60\right.$ for most of the time) and has slightly better correlations with nitrate particularly in winter (Fig. S5). Although the MO-OOA spectrum is similar during all seasons and also resembles that of low-volatility
OOA (LV-OOA) (Ng et al., 2011a), MO-OOA is still likely a mixed factor with different types of SOA. It cannot be separated with ME-2 in this study due to the limited chemical resolution of the ACSM measurements, for instance, the aqueous-phase SOA factor observed in winter (Sun et al., 2016b). Our results appear to be different from previous findings that LO-OOA tends to represent semi-volatile SOA that is generally correlated with nitrate, while MO-OOA usually represents low-volatility OOA that is generally corre- 

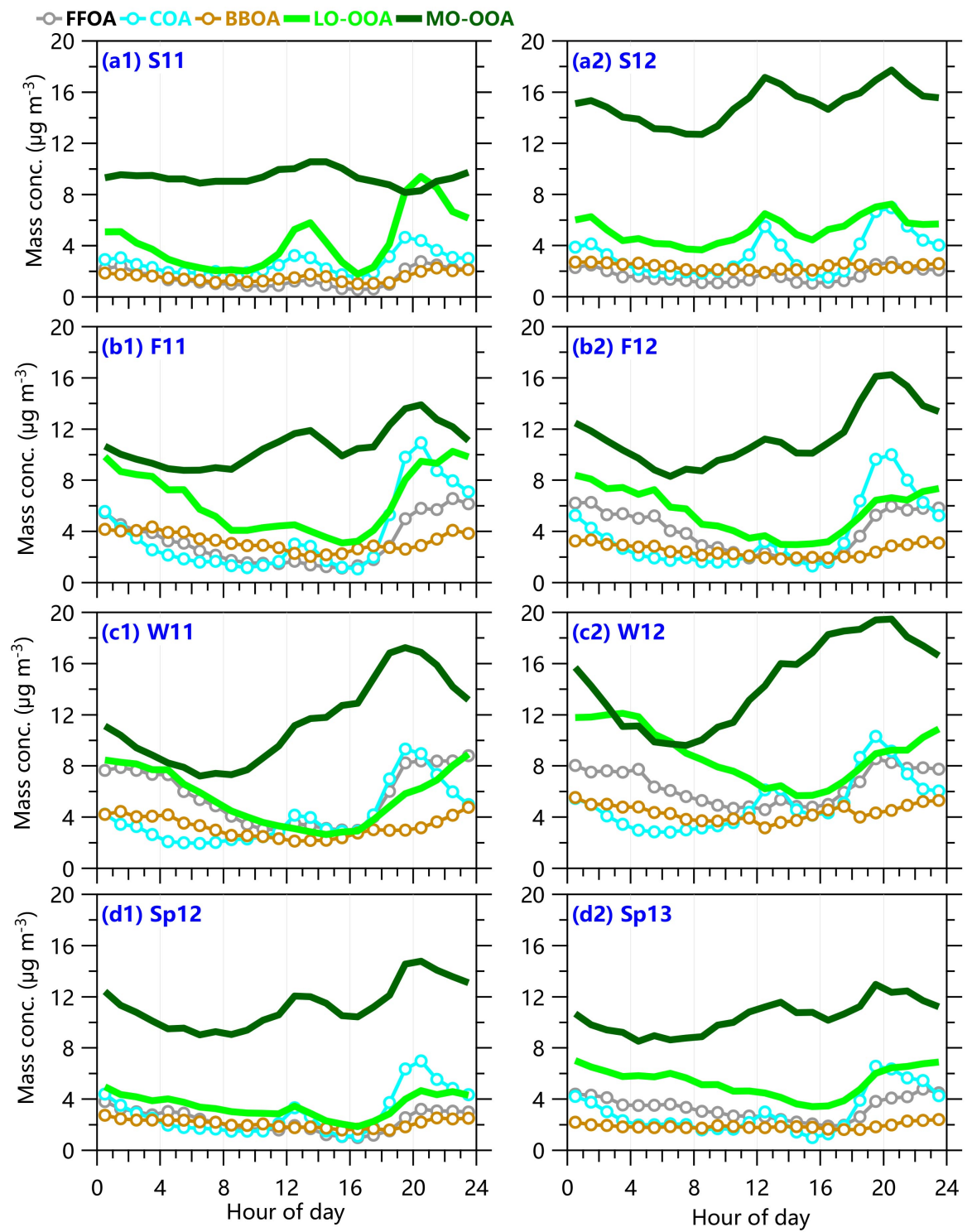

Figure 6. Average diurnal cycles of five OA factors during four seasons.

lated with sulfate (Lanz et al., 2007; Zhang et al., 2011). In fact, previous studies in Beijing show that LO-OOA is often weakly correlated with nitrate, for example, $r^{2}<0.12$ in fall 2015 (Zhao et al., 2017), likely indicating the different chemical processing between LO-OOA and nitrate. For example, the nighttime heterogeneous formation of nitrate was recently found to be similarly important to that of gas-particle partitioning of nitric acid (Wang et al., 2017), while the nighttime formation of LO-OOA is not clear yet. In addition, the similarly tight correlations between MO-OOA and secondary inorganic species highlight another fact that secondary aerosols in Beijing can have large contributions from regional transport (Sun et al., 2014). This is also consistent with the simultaneous increases during the formation stage of most polluted episodes (Zhao et al., 2013; Sun et al., 2016a). Overall, MO-OOA constitutes the largest fraction of OA mass among five OA factors during all seasons, and the contributions present a pronounced seasonal variation with the highest values in summer (47-64\%) and the lowest values in winter (30-34\%).

Table 1 presents a summary of monthly average concentrations and fractions of five OA factors. It is clear that the contributions of POA and SOA show strong seasonal differences. SOA (= LO-OOA + MO-OOA) shows the largest contribution to $\mathrm{OA}$ during the non-heating season by accounting for $65-75 \%$. Although the contributions decrease to $52-64 \%$ in the heating season, they are still higher than those of POA, indicating that SOA plays a more important role controlling OA chemistry than POA during all seasons. Consistently, the dominance of SOA in OA mass has been widely reported 
at various urban sites (Zhang et al., 2007; Jimenez et al., 2009). We also noticed the seasonal changes in SOA composition. For example, the contributions of LO-OOA generally exceed those of MO-OOA in the heating season. Compared with SOA, POA $(=\mathrm{FFOA}+\mathrm{BBOA}+\mathrm{COA})$ shows a large increase from $\sim 30 \%$ in summer to $\sim 40-50 \%$ in winter, and such increases are mainly driven by FFOA and BBOA from coal combustion and biomass burning emissions, respectively, supporting the large impacts of these two sources on POA in the heating season.

\subsection{Loading-dependent OA composition}

Figure 5 shows chemically resolved OA composition as a function of OA mass loadings during four seasons. In summer, the SOA contribution first shows an increase at low OA mass loadings $\left(<20 \mu \mathrm{g} \mathrm{m}^{-3}\right)$ and then remains at relatively high values $(\sim 70-74 \%)$ at high mass loadings. These results indicate that SOA plays a dominant role in OA across different OA mass loadings in summer. However, we observe a significant change in SOA composition as a function of OA mass loadings. In particular, LO-OOA shows large increases from $\sim 10 \%$ to nearly $30 \%$ associated with corresponding decreases in MO-OOA as OA mass loadings increase to $>40 \mu \mathrm{g} \mathrm{m}^{-3}$. These results suggest that the periods with high OA loadings facilitate the formation of less oxidized SOA. A change in POA composition was also observed in summer 2011, which is characterized by an increase in FFOA and a corresponding decrease in COA as a function of OA mass loadings. As discussed in Sect. 3.3, FFOA in summer presents a similarly pronounced diurnal profile as $\mathrm{COA}$ suggesting that FFOA and COA might not be well separated even with the constrained mass spectral profiles. In fact, the contributions of the sum of FFOA and COA are relatively stable across different OA mass loadings, which are $\sim 20$ $25 \%$ except for the period of OA $>65 \mu \mathrm{g} \mathrm{m}^{-3}$ in the summer of 2012 with significant BB impacts.

Similar mass-loading-dependent OA composition is also observed in the fall season, yet with some differences between 2011 and 2012 (Fig. 5b). The SOA contribution in fall 2011 first shows a large increase from $\sim 50$ to $65 \%$ at $\mathrm{OA}<30 \mu \mathrm{g} \mathrm{m}^{-3}$, then remains at relatively constant levels (67-69\%) at high OA mass loadings. In comparison, it is consistently high $(65-70 \%)$ at $\mathrm{OA}<50 \mu \mathrm{g} \mathrm{m}^{-3}$ with a slight decrease to $\sim 60 \%$ as OA mass loading increases in the fall of 2012. We also noticed large differences in BBOA and LOOOA contributions at low mass loadings $\left(\mathrm{OA}<15 \mu \mathrm{g} \mathrm{m}^{-3}\right)$ between 2011 and 2012, yet the total contribution of BBOA and LO-OOA was close. One of the reasons is the uncertainties in splitting BBOA and LO-OOA with the ME-2 analysis. Indeed, the mass spectrum of LO-OOA resembles that of BBOA during the two fall seasons (Fig. 1). Although the contributions of the sum of FFOA and COA are relatively constant across different mass loadings, which are 21-25 and $23-27 \%$ in the fall of 2011 and 2012, respectively, we ob- served a clear increase in FFOA contribution by nearly a factor of 2 as OA mass loading increases. One reason is due to the half-month period of the fall season (15-30 November) when FFOA shows a large increase because of residential heating (Wang et al., 2015). This is particularly clear for the bins with the largest OA mass loading (80-85 and 90-95 $\mathrm{ug} \mathrm{m}^{-3}$ in F11 and F12, respectively), which occurred mainly during the half-month period of the heating season (Fig. 2). As a result, the contribution of FFOA increased to 23 and $27 \%$ in 2011 and 2012, respectively, which was associated with a large decrease in MO-OOA (15 and $22 \%$, respectively).

The POA composition changes significantly as a function of OA mass loading in winter (Fig. 5c). The contribution of FFOA gradually increases from $3-7$ to $22-28 \%$ when OA mass loading increases from less than 20 to $>60 \mu \mathrm{g} \mathrm{m}^{-3}$, highlighting a largely enhanced role of FFOA during highly polluted periods. In comparison, the COA contribution shows a large decrease from $\sim 30$ to $<10 \%$ although the mass concentration is relatively stable at $\sim 5$ $6 \mu \mathrm{g} \mathrm{m}^{-3}$, consistent with our previous conclusion that $\mathrm{COA}$ is a more important POA during clean periods with low OA mass loadings. The total contribution of SOA shows a small decrease of $5-10 \%$ at high OA mass loading periods mainly due to the decreases in MO-OOA, yet it is still as high as $52-58 \%$. Such a result indicates that SOA is still important during the highly polluted periods in winter (Huang et al., 2014). The changes in OA composition as a function of OA mass loading in spring are similar to those in fall. The SOA contribution shows a decrease during more polluted periods, yet it is still higher than that of POA (56-64 vs. 36-44\%). Again, FFOA shows a large increase at high OA mass loading. For example, the FFOA contribution increases from 6-9 to $\sim 20 \%$ as OA increases from $<20$ to $>50 \mu \mathrm{g} \mathrm{m}^{-3}$. This is consistent with the fact that the spring season also consisted of a half month of heating season when OA presents the highest mass loading (Fig. 2)

\subsection{Diurnal variations in $\mathrm{OA}$ factors}

The diurnal profiles of five OA factors in four seasons are shown in Fig. 6. Similar to previous studies (Sun et al., 2011b; Ge et al., 2012), COA presents similar and pronounced diurnal cycles during all seasons, which are characterized by two peaks during lunch and dinner times, respectively. The nighttime COA peak is nearly twice that of noontime during all seasons except for summer indicating higher cooking emissions at nighttime coupled with shallower boundary layer height compared to the middle of the day (Tang et al., 2016). The contribution of COA to OA is correspondingly high at nighttime ( $\sim 20-25 \%)$, supporting the significant impact of cooking activities on OA loading in urban areas. FFOA presents the lowest concentrations throughout the day in summer, yet two small peaks corresponding to mealtimes are also observed. Such a diurnal pro- 
file is not expected as the traffic-related HOA typically peaks during rush hours. One of the reasons is that the FFOA factor was not fully resolved and was partially influenced by cooking organic aerosol. Previous summer studies (J. Sun et al., 2010; Y. L. Sun et al., 2012; Zhang et al., 2015) using quadrupole AMS or ACSM have indeed shown that PMF analysis has difficulty resolving traffic-related HOA from $\mathrm{COA}$ in summer due to their relatively similar mass spectra measured by unit mass resolution instruments. In comparison, PMF analysis of the high-resolution mass spectra of $\mathrm{OA}$ is able to separate HOA from COA in summer in Beijing (Huang et al., 2010; Hu et al., 2016), and the results show substantially different diurnal profiles between these two factors. Compared to summer, FFOA and COA can be relatively well separated during other seasons as indicated by the much smaller noon peaks of FFOA. As shown in Fig. 6, FFOA presents much higher concentrations at nighttime than daytime due to (1) the enhanced coal combustion emissions, and (2) traffic emissions from diesel trucks and heavy duty vehicles that are only allowed inside the city between 22:0006:00 LT (Han et al., 2009), and (3) shallow boundary layer (Tang et al., 2016). We also found that COA exceeds FFOA before midnight during most of the seasons although it shows a rapid decrease after 21:00 when cooking activities are significantly reduced. FFOA then becomes a more important primary OA after midnight until $\sim 11: 00$. These results indicate the different roles of primary OA at different times of the day. Compared to FFOA and COA, the diurnal profiles of BBOA are less pronounced with slightly higher concentrations at nighttime.

The diurnal profiles of the two SOA factors are different during most of the seasons. As shown in Fig. 6c, MO-OOA presents the largest increase during daytime in winter, and the concentration is continuously increased by a factor of 2 from 08:00 until 19:00, indicating the strong photochemical production of SOA. The continuous daytime increase of MO-OOA is interrupted by a temporal decrease in the late afternoon during the other three seasons, which is very likely due to the rising boundary layer height with the dilution effect exceeding the secondary production. Compared to the diurnal changes in mass concentrations, the contribution of MO-OOA to OA shows similar diurnal trends during all seasons (Fig. S6), and the contributions increase gradually from the early morning and reach the maximum values at 16:0017:00. For example, the contributions increase from 30 to 48 and $53 \%$ in winter 2011 and 2012, respectively (Fig. S6c), and from $\sim 40$ to $\sim 56 \%$ in the fall seasons (Fig. S5b). Although the contributions are decreased slightly at lunchtime in summer due to the largely increased COA, they are still as high as $47-52 \%$. Also note that MO-OOA constitutes the largest fraction in OA throughout the day during all seasons, highlighting the ubiquity and dominance of SOA at urban sites (Zhang et al., 2007; Jimenez et al., 2009).

The diurnal profiles of LO-OOA are overall similar during three seasons - winter, spring, and autumn. The concentra- tions decrease gradually during daytime, reach the minimum values typically between 16:00 and 17:00, and then increase rapidly during the rest time of the day. Such diurnal profiles are exactly opposite to those of temperatures, likely indicating that gas partitioning driven by $T$ plays the dominant role. Higher concentrations at nighttime than daytime also resemble those of FFOA somewhat, which highlights another possibility, namely that LO-OOA is a combustion-related SOA as discussed above. It should be noted that the decreases in LO-OOA correspond to the increases in MO-OOA, which likely indicates the continuous transformation of LO-OOA into MO-OOA due to photochemical aging (Morgan et al., 2010; Sun et al., 2011a). LO-OOA presents a very different diurnal profile in summer compared to those during the other three seasons, which is characterized by similar COA peaks at lunch and dinner times. One explanation is that LOOOA was not well separated from COA in summer and was mixed with part of COA. Another explanation is that part of LO-OOA in summer was from the oxidation of VOCs from cooking emissions, which is consistent with a recent study showing that aging of different cooking aerosol can form less oxidized SOA (O / C = 0.24-0.46) (Liu et al., 2017b). Overall, SOA dominates OA throughout the day during all seasons. The contributions vary between 60 and $80 \%$ in spring, summer, and fall although they are decreased to 50-60\% in winter. These results indicate that secondary formation processes in winter via either photochemical and/or aqueousphase reactions could be as important as primary emissions.

\subsection{RH and $T(\mathrm{RH} / T)$ dependence of OA}

The RH / $T$ dependence of NR-PM ${ }_{1}$ species in Beijing is presented in Sun et al. (2015). Here, we mainly focus on the impacts of $\mathrm{RH}$ and $T$ on OA factors. As shown in Fig. 7a1, FFOA presents the highest concentrations in the bottom right-hand region with low $T$ and high RH. This is consistent with the significantly enhanced primary emissions (e.g., coal combustion and biomass burning) in winter. At similarly low $T$ levels, FFOA concentrations increase substantially as a function of RH particularly at RH $>50 \%$. In winter, the periods with high RH levels are typically characterized by stagnant meteorological conditions, e.g., low wind speed (Fig. S7a) and shallow boundary layer height (Tang et al., 2016), which lead to the accumulation of primary pollutants and the increases in FFOA concentrations. However, the ratios of FFOA / OA also present high values in the similar bottom right-hand region (Fig. 7a2) indicating that high RH conditions could also facilitate the formation of more FFOA from coal combustion emissions (Sun et al., 2013a).

Compared with FFOA, the concentration gradients of COA as a function of $\mathrm{RH} / T$ are much smaller (Fig. 7b). The COA emissions are relatively constant throughout the year and are not expected to have a strong $\mathrm{RH} / T$ dependence. Thus, the concentration gradients of COA would be mainly caused by the dilution or accumulation effects. For 

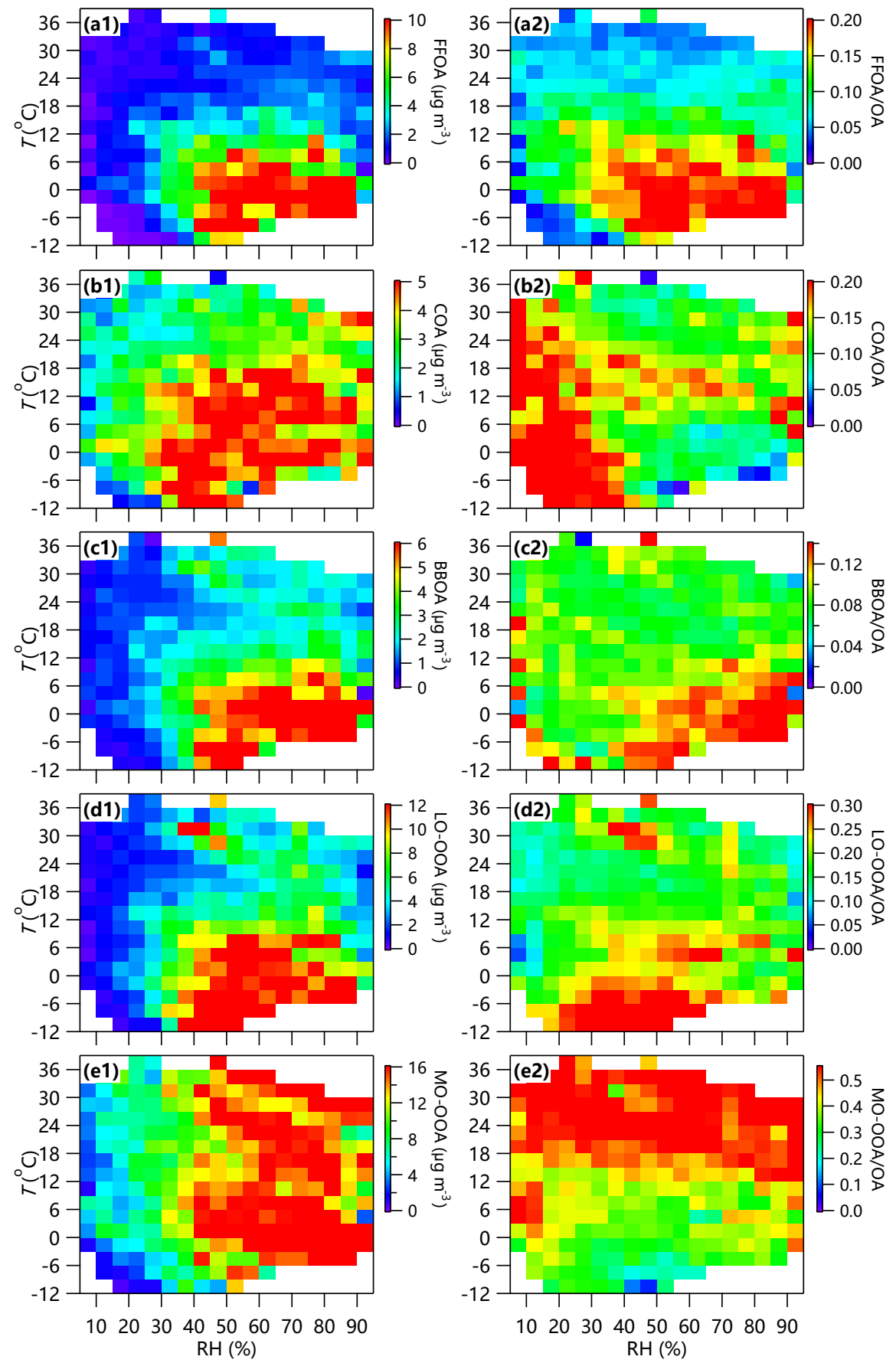

Figure 7. RH / $T$ dependence of mass concentrations and mass fractions of five OA factors for the entire study. The data are grouped into grids with increments of RH and $T$ being $5 \%$ and $3{ }^{\circ} \mathrm{C}$, respectively. Grid cells with the number of data points fewer than 10 are excluded.

example, low concentrations in the left region $(\mathrm{RH}<30 \%)$ are mainly caused by high WS (Fig. S7a), while high values in the bottom right-hand region are mainly due to the stagnant conditions, which is consistent with the concentration gradients of FFOA. However, the RH / $T$ dependence of $\mathrm{COA} / \mathrm{OA}$ is largely different from that of FFOA / OA. In particular, COA / OA presents the highest values at low RH levels $(<30 \%)$ across different $T$ levels. These results highlight the dominant role of COA in OA in clean periods during all seasons. We further evaluated the $\mathrm{RH} / T$ dependence of FFOA / COA (Fig. S7b). Because FFOA is from both traffic and seasonal dependent coal combustion emissions, the ratio 

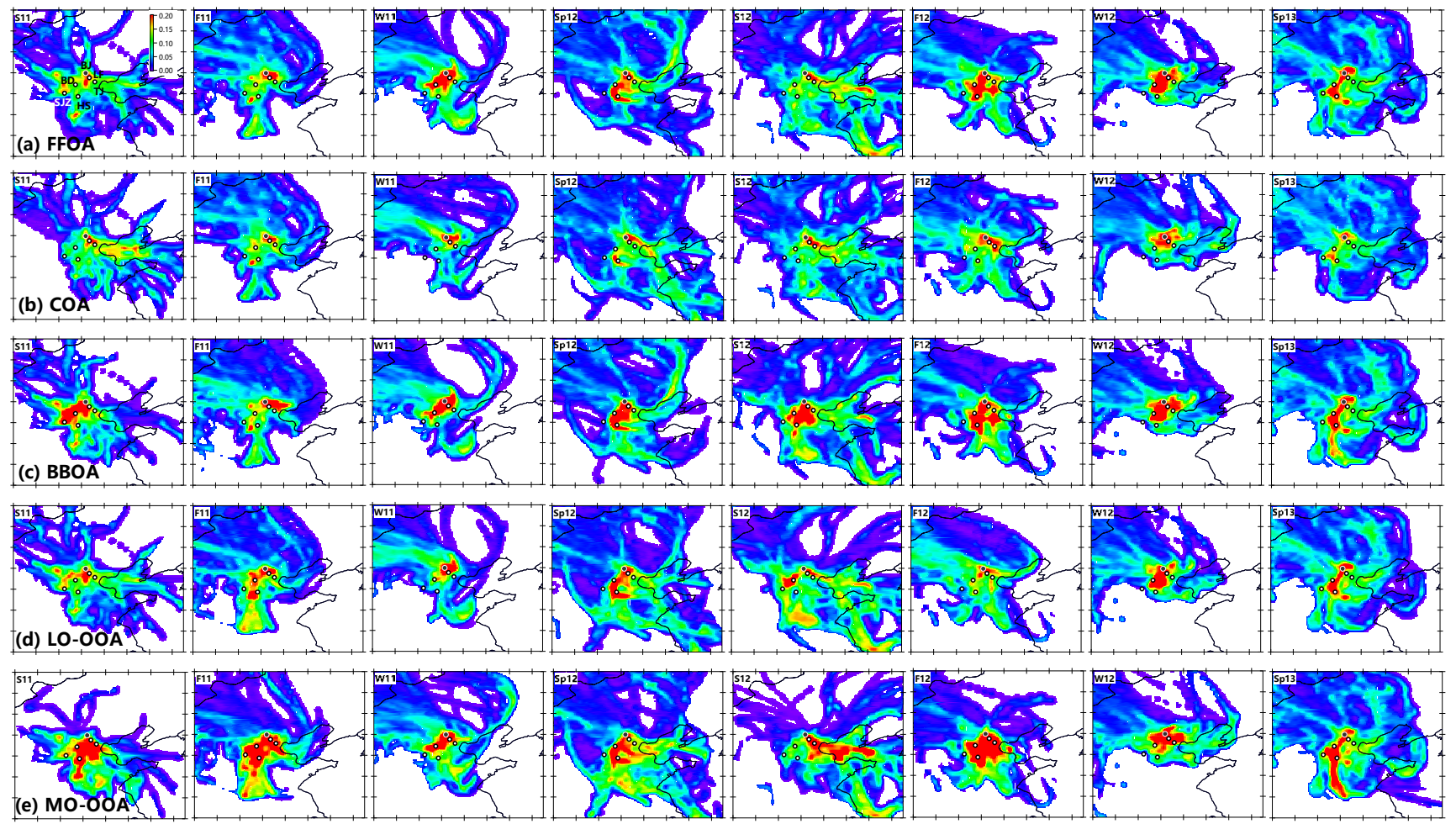

Figure 8. PSCF of five OA factors in each season. The cities marked as solid circles in each panel are Tianjing (TJ), Langfang (LF), Baoding (BD), Shijiazhuang (SJZ), and Hengshui (HS). The color scales indicate the values of PSCF.

of FFOA / COA can be used as a diagnostic for the impacts of source emissions. Indeed, the highest FFOA / COA ratio ( $>1.5$ ) occurred when $T<6^{\circ} \mathrm{C}$ and $\mathrm{RH}>40 \%$ (Fig. S7b), supporting more FFOA emissions, e.g., from coal combustion, at lower $T$ and higher RH levels.

The RH / $T$ dependence of BBOA is similar to that of FFOA (Fig. 7c), which shows higher concentrations in the bottom right-hand region, indicating more biomass burning emissions at high RH levels in winter. The contribution of BBOA to OA is relatively constant at $\sim 6-10 \%$ across different $\mathrm{RH}$ and $T$ levels except for the high contribution in the region with $\mathrm{RH}>70 \%$ and low $T\left(-6-0{ }^{\circ} \mathrm{C}\right)$. Such a result could be potentially important for a better understanding of aqueous-phase SOA formation as a recent study found that aqueous-phase processing of biomass burning emissions can contribute to ambient SOA formation substantially (Gilardoni et al., 2016).

The RH / $T$ dependences of two SOA factors are very different. As shown in Fig. 7d, LO-OOA presents the highest concentrations in the region with $\mathrm{RH}>40 \%$ and $T<6^{\circ} \mathrm{C}$. Although such a distribution is similar to that of FFOA, we also observed moderately high concentrations at high $T$ when RH is above $60 \%$. The RH / T dependence of LOOOA / OA is also different from those of other OA factors. The dominance of LO-OOA $(\sim 30 \%)$ is observed in the bottom region with $T$ below $0{ }^{\circ} \mathrm{C}$, while it was similarly impor- tant in other regions with different $\mathrm{RH}$ and $T$ levels. These results indicate two different formation mechanisms of LOOOA. While gas-particle partitioning plays a dominant role in LO-OOA formation at low $T$, photochemical production becomes more important during other periods. Compared with LO-OOA, the MO-OOA concentrations show strong RH dependence during all seasons while the $T$ dependence is not clear (Fig. 7e). Such a distribution illustrates that aqueous-phase processing might be an important mechanism in the formation of MO-OOA. This is also supported by the correlations between MO-OOA and sulfate, a species dominantly from cloud and aqueous-phase processing, during all seasons. However, the contribution of MO-OOA to OA presents a strong $T$ dependence with much higher contributions at $T>18^{\circ} \mathrm{C}$ than those below $12^{\circ} \mathrm{C}(\sim>50$ vs. $\sim 30$ $40 \%)$. Such a $T$-dependent MO-OOA/OA clearly highlights the importance of MO-OOA in summer over other seasons across different RH levels.

\subsection{Potential source regions of $\mathrm{OA}$}

Figure 8 shows the PSCF analysis of five OA factors during four seasons. FFOA shows high PSCF values in a small region near the sampling site in the summer seasons of 2011 and 2012, supporting the dominant source of local emissions. This is consistent with the fact that FFOA in summer is mainly from traffic-related emissions. While FFOA shows 
a similarly dominant local source in the fall of 2011, it is also characterized by a high-PSCF region to the southwest of Beijing in the fall of 2012. These results indicate that FFOA can have very different contributions from local sources and regional transport in the same season in different years. In the winters of 2011 and 2012, FFOA shows high PSCF values in the regions located to the south and southwest of Beijing, indicating that regional transport plays an important role for the high concentrations of FFOA in winter in Beijing. In fact, the coal boilers for residential heating have all been replaced with natural gas inside Beijing city, and a large contribution of FFOA at the sampling site would be expected from regional transport (Cheng et al., 2016; Sun et al., 2017). For example, Sun et al. (2014) found that regional transport may have contributed $84 \%$ of coal combustion emissions during the peak of severe haze pollution in 12-13 January 2013. Note that the high PSCF does not extend beyond the cities of Shijiazhuang and Hengshui, suggesting that transport is mainly dominant in a region less than $250 \mathrm{~km}$ away. This is consistent with the results from a recent study that state that the regional transport during severe haze episodes is dominantly from the south/southwest (e.g., Baoding, Cangzhou, and Hengshui) and south/southeast (e.g., Langfang and Tianjin), while that from regions farther away, e.g., Shijiazhuang, Xiangtai, and Handan is negligible ( $\mathrm{Li}$ et al., 2017a). The contribution of regional transport to high FFOA concentrations is even more important in the spring seasons of 2012 and 2013, which is characterized by a narrow high-PSCF band along Taihang Mountains. The cities of Baoding and Hengshui (approximately $250 \mathrm{~km}$ from Beijing) are both potential source regions of Beijing FFOA. These results are consistent with the wind rose plots in Fig. S8 showing more frequency of high WS from the southwest in spring than winter. Therefore, reducing coal combustion emissions in the regions to the south/southwest of Beijing would greatly help mitigate FFOA pollution in Beijing in the winter season.

Compared to FFOA, the regions with high PSCF values for COA are much smaller during all seasons, consistent with the fact that COA is dominantly from local cooking emissions. In addition, a small high-PSCF region (typically less than $50 \mathrm{~km}$ ) located to the east/southeast is frequently observed in many seasons, indicating that short-distance transport could contribute the high COA at our sampling site. However, some hot spots near Hengshui (HS) and Baoding (BD) are more likely from artifacts and are not expected to be an important source of COA in Beijing. For example, a recent modeling study found that the COA concentrations decrease rapidly outside of the city and could not have a significant impact on rural areas (Ots et al., 2016). As shown in Fig. 8c, the PSCF regions of BBOA are very similar to those of FFOA in fall, winter, and spring seasons. We also noticed that BBOA is moderately correlated with FFOA during these three seasons $\left(r^{2}=0.44-0.80\right.$, Fig. S5), suggesting similar seasonal emission characteristics between BBOA and FFOA. Previous studies have shown that residential emissions contribute substantially to the regional air pollution in northern China in winter (Liu et al., 2016). While coal is the dominant fuel for residential heating in winter, biomass is also an important fuel (Liu et al., 2017a). Not surprisingly, coal combustion and biomass burning show similar temporal variations in winter. As discussed above, high concentrations of FFOA and BBOA in spring and fall mainly occur during the halfmonth period in the heating season (15-30 November and 115 March), and the high-PSCF regions of BBOA and FFOA in these two seasons are consistently contributed by the high concentrations during these two periods. The PSCF region of BBOA is quite different from that of FFOA in summer, indicating their different source regions. While FFOA in summer is dominantly contributed by local traffic emissions, BBOA still has an important source from regional transport.

The potential source regions of the two SOA factors are quite different in different seasons (Fig. 8d, e). In the spring seasons of 2012 and 2013, both LO-OOA and MO-OOA show similar potential source regions as those of FFOA and BBOA with high PSCF values located to the southwest of Beijing. These results indicate that regional transport from the southwest is an important contribution of both primary and secondary OA. Figure 8e also shows high-potential source regions of MO-OOA that are nearly twice as far away as those of LO-OOA and FFOA in spring 2012, consistent with the formation of more oxidized SOA over a wider regional scale. During the other three seasons, MO-OOA shows ubiquitously wider potential source regions than LOOOA, suggesting that the formation of MO-OOA is more regional than LO-OOA. This is also consistent with the good correlations between MO-OOA with sulfate that is mainly formed over a regional scale (Zhang et al., 2012). For instance, the potential source region of LO-OOA is limited to a small region to the south of Beijing in summer 2011, while that of MO-OOA is beyond approximately $250 \mathrm{~km}$. These results suggest that LO-OOA in summer is likely mainly from local photochemical production while MO-OOA has more contributions from regional transport. Even in the same season, the source regions could be different. For example, LOOOA presents two potential source regions located to the southwest and southeast of Beijing, respectively, while that of MO-OOA is dominantly from the southeast. Note that a potential source region over the Bo Hai Sea was also observed for MO-OOA. One explanation is that MO-OOA from a regional scale was circulated from the Bo Hai Sea before arriving at Beijing. Indeed, the periods with high concentrations of MO-OOA in summer 2012 (19-21 June) show clear transport from Bo Hai Sea to Beijing as indicated by Fig. S9. Compared to other seasons, the potential source region of MO-OOA in winter is much smaller, which is mainly located to the southwest in 2011, and the whole south of Beijing in winter 2012, while the highly polluted cities, e.g., Shijiazhuang and Hengshui in Hebei province, appear not to contribute significantly to both POA and SOA in Beijing. These results highlight the importance of employing different con- 
trol strategies in reducing the number of severely polluted days in Beijing in different seasons; in particular, more efforts are needed to control emissions in the surrounding regions within $250 \mathrm{~km}$ in winter.

\section{Conclusions}

An aerosol chemical speciation monitor was deployed at an urban site in Beijing for 2-year real-time measurements of NR-PM 1 species from July 2011 to May 2013. Organics present a pronounced seasonal variation, with the average concentration in winter being twice higher than the average in summer mainly due to coal combustion emissions in the heating season. The ME-2 analysis of seasonal datasets identified five OA factors during all seasons, including FFOA from traffic and coal combustion emissions, BBOA, COA, LO-OOA, and MO-OOA. FFOA and BBOA present similar seasonal variations with high concentrations in the heating season, which are mainly caused by enhanced coal combustion and biomass burning emissions in winter. Comparatively, the seasonal variation in COA is much less pronounced, and the average contributions are relatively constant (10-15\%) across different seasons. A high concentration of BBOA is also observed in June due to agricultural burning impacts. The seasonal variation in LO-OOA is more similar to that of FFOA and BBOA, likely indicating that LO-OOA is a combustion-related SOA, and gas-particle partitioning under low $T$ plays a major role. This is also consistent with the diurnal profile, which presents much higher concentrations at nighttime than daytime during most of the seasons. MO-OOA constitutes the largest fraction in OA during all seasons, and the contributions present a pronounced seasonal variation with the highest values in summer (47$64 \%$ ) and the lowest values in winter (30-34\%).

The chemically resolved OA composition demonstrates the different roles of OA factors at different levels of pollution. While SOA dominates OA across different mass loadings during all seasons, a large increase in FFOA contribution as a function of OA mass loading was also observed, particularly in winter, indicating an enhanced role of coal combustion emissions during severely polluted episodes. The RH / $T$ dependence of OA factors shows ubiquitously high concentrations at low $T$ and high $\mathrm{RH}$, elucidating the highest frequency of severe haze episodes at high $\mathrm{RH}$ conditions in winter. COA presents the weakest $\mathrm{RH} / T$ dependence among OA factors, yet the contribution to OA is much higher at $\mathrm{RH}<30 \%$, highlighting the important role of COA during clean periods. MO-OOA shows higher concentrations at higher RH levels across different $T$ levels and is also correlated with both nitrate and sulfate during all seasons, indicating the formation of MO-OOA from both aqueous-phase and photochemical processing. The potential source regions of five OA factors are further investigated with PSCF analysis, which show different source regions between primary and secondary OA across different seasons.

Data availability. The data in this study are available from the authors upon request (sunyele@mail.iap.ac.cn). 
Appendix A: List of abbreviations

\begin{tabular}{ll}
\hline ACSM & Aerosol chemical speciation monitor \\
HR-AMS & High-resolution time-of-flight aerosol mass spectrometer \\
CAPS & Cavity attenuated phase shift \\
NR-PM & Non-refractory submicron aerosol \\
OA & Organic aerosol \\
SOA & Secondary organic aerosol \\
POA & Primary organic aerosol \\
FFOA & Fossil-fuel-related organic aerosol \\
HOA & Hydrocarbon-like organic aerosol \\
COA & Cooking organic aerosol \\
CCOA & Coal combustion organic aerosol \\
BBOA & Biomass burning organic aerosol \\
OOA & Oxygenated organic aerosol \\
LO-OOA & Less-oxidized oxygenated organic aerosol \\
MO-OOA & More-oxidized oxygenated organic aerosol \\
LV-OOA & Low-volatility oxygenated organic aerosol \\
ME-2 & Multilinear engine \\
PMF & Positive matrix factorization \\
PSCF & Potential source contribution function \\
VOCs & Volatile organic compounds \\
WD & Wind direction \\
WS & Wind speed \\
RH & Relative humidity \\
$T$ & Temperature \\
MLH & Mixing layer height \\
&
\end{tabular}


Supplement. The supplement related to this article is available online at: https://doi.org/10.5194/acp-18-8469-2018-supplement.

Competing interests. The authors declare that they have no conflict of interest.

Acknowledgements. This work was supported by the National Natural Science Foundation of China (41575120, 91744207, 41571130034) and the National Key Project of Basic Research (2014CB447900).

Edited by: Sachin S. Gunthe

Reviewed by: two anonymous referees

\section{References}

Boucher, O., Randall, D., Artaxo, P., Bretherton, C., Feingold, G., Forster, P., Kerminen, V.-M., Kondo, Y., Liao, H., Lohmann, U., Rasch, P., Satheesh, S. K., Sherwood, S., Stevens, B., and Zhang, X. Y.: Clouds and aerosols, in: Climate change 2013: the physical science basis. Contribution of Working Group I to the Fifth Assessment Report of the Intergovernmental Panel on Climate Change, Cambridge University Press, Cambridge, United Kingdom and New York, NY, USA, 2013.

Bressi, M., Cavalli, F., Belis, C. A., Putaud, J.-P., Fröhlich, R., Martins dos Santos, S., Petralia, E., Prévôt, A. S. H., Berico, M., Malaguti, A., and Canonaco, F.: Variations in the chemical composition of the submicron aerosol and in the sources of the organic fraction at a regional background site of the Po Valley (Italy), Atmos. Chem. Phys., 16, 12875-12896, https://doi.org/10.5194/acp-16-12875-2016, 2016.

Canagaratna, M., Jayne, J., Jimenez, J. L., Allan, J. A., Alfarra, R., Zhang, Q., Onasch, T., Drewnick, F., Coe, H., Middlebrook, A., Delia, A., Williams, L., Trimborn, A., Northway, M., Kolb, C., Davidovits, P., and Worsnop, D.: Chemical and microphysical characterization of aerosols via Aerosol Mass Spectrometry, Mass Spectrom. Rev., 26, 185-222, 2007.

Canonaco, F., Crippa, M., Slowik, J. G., Baltensperger, U., and Prévôt, A. S. H.: SoFi, an IGOR-based interface for the efficient use of the generalized multilinear engine (ME2) for the source apportionment: ME-2 application to aerosol mass spectrometer data, Atmos. Meas. Tech., 6, 3649-3661, https://doi.org/10.5194/amt-6-3649-2013, 2013.

Chen, J., Li, C., Ristovski, Z., Milic, A., Gu, Y., Islam, M. S., Wang, S., Hao, J., Zhang, H., He, C., Guo, H., Fu, H., Miljevic, B., Morawska, L., Thai, P., Lam, Y. F., Pereira, G., Ding, A., Huang, X., and Dumka, U. C.: A review of biomass burning: Emissions and impacts on air quality, health and climate in China, Sci. Total Environ., 579, 1000-1034, 2017.

Cheng, N., Zhang, D., Li, Y., and Fan, M.: Residential emissions in Beijing: About $400 \times 10^{4}$ t, P. Natl. Acad. Sci. USA, 113, E5778-E5779, https://doi.org/10.1073/pnas.1613118113, 2016.

Draxler, R. R. and Rolph, G. D.: HYSPLIT (HYbrid Single-Particle Lagrangian Integrated Trajectory), NOAA Air Resources Laboratory, College Park, MD, USA, Model access via NOAA
ARL READY Website, available at: http://www.arl.noaa.gov/ HYSPLIT.php (last access: 20 March 2017), 2013.

Elser, M., Huang, R.-J., Wolf, R., Slowik, J. G., Wang, Q., Canonaco, F., Li, G., Bozzetti, C., Daellenbach, K. R., Huang, Y., Zhang, R., Li, Z., Cao, J., Baltensperger, U., El-Haddad, I., and Prévôt, A. S. H.: New insights into $\mathrm{PM}_{2.5}$ chemical composition and sources in two major cities in China during extreme haze events using aerosol mass spectrometry, Atmos. Chem. Phys., 16, 3207-3225, https://doi.org/10.5194/acp-16-3207-2016, 2016.

Fast, J. D., Allan, J., Bahreini, R., Craven, J., Emmons, L., Ferrare, R., Hayes, P. L., Hodzic, A., Holloway, J., Hostetler, C., Jimenez, J. L., Jonsson, H., Liu, S., Liu, Y., Metcalf, A., Middlebrook, A., Nowak, J., Pekour, M., Perring, A., Russell, L., Sedlacek, A., Seinfeld, J., Setyan, A., Shilling, J., Shrivastava, M., Springston, S., Song, C., Subramanian, R., Taylor, J. W., Vinoj, V., Yang, Q., Zaveri, R. A., and Zhang, Q.: Modeling regional aerosol and aerosol precursor variability over California and its sensitivity to emissions and long-range transport during the $2010 \mathrm{CalNex}$ and CARES campaigns, Atmos. Chem. Phys., 14, 10013-10060, https://doi.org/10.5194/acp-14-10013-2014, 2014.

Fu, T.-M., Cao, J. J., Zhang, X. Y., Lee, S. C., Zhang, Q., Han, Y. M., Qu, W. J., Han, Z., Zhang, R., Wang, Y. X., Chen, D., and Henze, D. K.: Carbonaceous aerosols in China: top-down constraints on primary sources and estimation of secondary contribution, Atmos. Chem. Phys., 12, 2725-2746, https://doi.org/10.5194/acp12-2725-2012, 2012.

Ge, B., Sun, Y., Liu, Y., Dong, H., Ji, D., Jiang, Q., Li, J., and Wang, Z.: Nitrogen dioxide measurement by cavity attenuated phase shift spectroscopy (CAPS) and implications in ozone production efficiency and nitrate formation in Beijing, China, J. Geophys. Res., 118, 9499-9509, https://doi.org/10.1002/jgrd.50757, 2013.

Ge, X., Setyan, A., Sun, Y., and Zhang, Q.: Primary and secondary organic aerosols in Fresno, California during wintertime: Results from high resolution aerosol mass spectrometry, J. Geophys. Res., 117, D19301, https://doi.org/10.1029/2012JD018026, 2012.

Gilardoni, S., Massoli, P., Paglione, M., Giulianelli, L., Carbone, C., Rinaldi, M., Decesari, S., Sandrini, S., Costabile, F., Gobbi, G. P., Pietrogrande, M. C., Visentin, M., Scotto, F., Fuzzi, S., and Facchini, M. C.: Direct observation of aqueous secondary organic aerosol from biomassburning emissions, P. Natl. Acad. Sci. USA, 113, 10013-10018, https://doi.org/10.1073/pnas.1602212113, 2016.

Guo, S., Hu, M., Zamora, M. L., Peng, J., Shang, D., Zheng, J., Du, Z., Wu, Z., Shao, M., Zeng, L., Molina, M. J., and Zhang, R.: Elucidating severe urban haze formation in China, P. Natl. Acad. Sci. USA, 111, 17373-17378, https://doi.org/10.1073/pnas.1419604111, 2014.

Hallquist, M., Wenger, J. C., Baltensperger, U., Rudich, Y., Simpson, D., Claeys, M., Dommen, J., Donahue, N. M., George, C., Goldstein, A. H., Hamilton, J. F., Herrmann, H., Hoffmann, T., Iinuma, Y., Jang, M., Jenkin, M. E., Jimenez, J. L., Kiendler-Scharr, A., Maenhaut, W., McFiggans, G., Mentel, Th. F., Monod, A., Prévôt, A. S. H., Seinfeld, J. H., Surratt, J. D., Szmigielski, R., and Wildt, J.: The formation, properties and impact of secondary organic aerosol: current and emerging issues, Atmos. Chem. Phys., 9, 5155-5236, https://doi.org/10.5194/acp9-5155-2009, 2009. 
Han, S., Kondo, Y., Oshima, N., Takegawa, N., Miyazaki, Y., Hu, M., Lin, P., Deng, Z., Zhao, Y., Sugimoto, N., and Wu, Y.: Temporal variations of elemental carbon in Beijing, J. Geophys. Res., 114, D23202, https://doi.org/10.1029/2009JD012027, 2009.

Hu, W., Hu, M., Hu, W., Jimenez, J. L., Yuan, B., Chen, W., Wang, M., Wu, Y., Chen, C., Wang, Z., Peng, J., Zeng, L., and Shao, M.: Chemical composition, sources and aging process of submicron aerosols in Beijing: contrast between summer and winter, J. Geophys. Res., 121, 1955-1977, https://doi.org/10.1002/2015JD024020, 2016.

Hu, W., Hu, M., Hu, W.-W., Zheng, J., Chen, C., Wu, Y., and Guo, S.: Seasonal variations in high time-resolved chemical compositions, sources, and evolution of atmospheric submicron aerosols in the megacity Beijing, Atmos. Chem. Phys., 17, 9979-10000, https://doi.org/10.5194/acp-17-9979-2017, 2017.

Huang, R.-J., Zhang, Y., Bozzetti, C., Ho, K.-F., Cao, J.-J., Han, Y., Daellenbach, K. R., Slowik, J. G., Platt, S. M., Canonaco, F., Zotter, P., Wolf, R., Pieber, S. M., Bruns, E. A., Crippa, M., Ciarelli, G., Piazzalunga, A., Schwikowski, M., Abbaszade, G., SchnelleKreis, J., Zimmermann, R., An, Z., Szidat, S., Baltensperger, U., Haddad, I. E., and Prévôt, A. S. H.: High secondary aerosol contribution to particulate pollution during haze events in China, Nature, 514, 218-222, https://doi.org/10.1038/nature13774, 2014.

Huang, X.-F., He, L.-Y., Hu, M., Canagaratna, M. R., Sun, Y., Zhang, Q., Zhu, T., Xue, L., Zeng, L.-W., Liu, X.-G., Zhang, Y.-H., Jayne, J. T., Ng, N. L., and Worsnop, D. R.: Highly time-resolved chemical characterization of atmospheric submicron particles during 2008 Beijing Olympic Games using an Aerodyne High-Resolution Aerosol Mass Spectrometer, Atmos. Chem. Phys., 10, 8933-8945, https://doi.org/10.5194/acp-108933-2010, 2010.

Jayne, J. T., Leard, D. C., Zhang, X., Davidovits, P., Smith, K. A., Kolb, C. E., and Worsnop, D. R.: Development of an aerosol mass spectrometer for size and composition analysis of submicron particles, Aerosol Sci. Tech., 33, 49-70, 2000.

Jiang, Q., Sun, Y., Wang, Z., and Yin, Y.: Real-time online measurements of the inorganic and organic composition of haze fine particles with an Aerosol Chemical Speciation Monitor (ACSM), Chinese Sci. Bull., 58, 3818-3828, 2013 (in Chinese).

Jiang, Q., Sun, Y. L., Wang, Z., and Yin, Y.: Aerosol composition and sources during the Chinese Spring Festival: fireworks, secondary aerosol, and holiday effects, Atmos. Chem. Phys., 15, 6023-6034, https://doi.org/10.5194/acp-15-6023-2015, 2015.

Jimenez, J. L., Canagaratna, M. R., Donahue, N. M., Prevot, A. S. H., Zhang, Q., Kroll, J. H., DeCarlo, P. F., Allan, J. D., Coe, H., Ng, N. L., Aiken, A. C., Docherty, K. S., Ulbrich, I. M., Grieshop, A. P., Robinson, A. L., Duplissy, J., Smith, J. D., Wilson, K. R., Lanz, V. A., Hueglin, C., Sun, Y. L., Tian, J., Laaksonen, A., Raatikainen, T., Rautiainen, J., Vaattovaara, P., Ehn, M., Kulmala, M., Tomlinson, J. M., Collins, D. R., Cubison, M. J., E, Dunlea, J., Huffman, J. A., Onasch, T. B., Alfarra, M. R., Williams, P. I., Bower, K., Kondo, Y., Schneider, J., Drewnick, F., Borrmann, S., Weimer, S., Demerjian, K., Salcedo, D., Cottrell, L., Griffin, R., Takami, A., Miyoshi, T., Hatakeyama, S., Shimono, A., Sun, J. Y., Zhang, Y. M., Dzepina, K., Kimmel, J. R., Sueper, D., Jayne, J. T., Herndon, S. C., Trimborn, A. M., Williams, L. R., Wood, E. C., Middlebrook, A. M., Kolb, C. E., Baltensperger, U., and Worsnop, D. R.: Evolution of organic aerosols in the atmosphere, Science, 326, 1525-1529, https://doi.org/10.1126/science.1180353, 2009.

Kebabian, P. L., Wood, E. C., Herndon, S. C., and Freedman, A.: A Practical Alternative to Chemiluminescence-Based Detection of Nitrogen Dioxide: Cavity Attenuated Phase Shift Spectroscopy, Environ. Sci. Technol., 42, 6040-6045, https://doi.org/10.1021/es703204j, 2008.

Lanz, V. A., Alfarra, M. R., Baltensperger, U., Buchmann, B., Hueglin, C., and Prévôt, A. S. H.: Source apportionment of submicron organic aerosols at an urban site by factor analytical modelling of aerosol mass spectra, Atmos. Chem. Phys., 7, 15031522, https://doi.org/10.5194/acp-7-1503-2007, 2007.

Li, J., Du, H., Wang, Z., Sun, Y., Yang, W., Li, J., Tang, X., and Fu, P.: Rapid formation of a severe regional winter haze episode over a mega-city cluster on the North China Plain, Environ. Pollut., 223, 605-615, 2017a.

Li, Y. J., Sun, Y., Zhang, Q., Li, X., Li, M., Zhou, Z., and Chan, C. K.: Real-time chemical characterization of atmospheric particulate matter in China: A review, Atmos. Environ., 158, 270-304, 2017b.

Liu, J., Mauzerall, D. L., Chen, Q., Zhang, Q., Song, Y., Peng, W., Klimont, Z., Qiu, X., Zhang, S., Hu, M., Lin, W., Smith, K. R., and Zhu, T.: Air pollutant emissions from Chinese households: A major and underappreciated ambient pollution source, $\mathrm{P}$. Natl. Acad. Sci. USA, https://doi.org/10.1073/pnas.1604537113, 2016.

Liu, P., Zhang, C., Xue, C., Mu, Y., Liu, J., Zhang, Y., Tian, D., Ye, C., Zhang, H., and Guan, J.: The contribution of residential coal combustion to atmospheric $\mathrm{PM}_{2.5}$ in northern China during winter, Atmos. Chem. Phys., 17, 11503-11520, https://doi.org/10.5194/acp-17-11503-2017, 2017a.

Liu, T., Li, Z., Chan, M., and Chan, C. K.: Formation of secondary organic aerosols from gas-phase emissions of heated cooking oils, Atmos. Chem. Phys., 17, 7333-7344, https://doi.org/10.5194/acp-17-7333-2017, 2017 b.

Middlebrook, A. M., Bahreini, R., Jimenez, J. L., and Canagaratna, M. R.: Evaluation of composition-dependent collection efficiencies for the Aerodyne Aerosol Mass Spectrometer using field data, Aerosol Sci. Tech., 46, 258-271, 2012.

Minguillón, M. C., Ripoll, A., Pérez, N., Prévôt, A. S. H., Canonaco, F., Querol, X., and Alastuey, A.: Chemical characterization of submicron regional background aerosols in the western Mediterranean using an Aerosol Chemical Speciation Monitor, Atmos. Chem. Phys., 15, 6379-6391, https://doi.org/10.5194/acp-15-6379-2015, 2015.

Morgan, W. T., Allan, J. D., Bower, K. N., Highwood, E. J., Liu, D., McMeeking, G. R., Northway, M. J., Williams, P. I., Krejci, R., and Coe, H.: Airborne measurements of the spatial distribution of aerosol chemical composition across Europe and evolution of the organic fraction, Atmos. Chem. Phys., 10, 4065-4083, https://doi.org/10.5194/acp-10-4065-2010, 2010.

Ng, N. L., Canagaratna, M. R., Jimenez, J. L., Zhang, Q., U1brich, I. M., and Worsnop, D. R.: Real-time methods for estimating organic component mass concentrations from Aerosol Mass Spectrometer data, Environ. Sci. Technol., 45, 910-916, https://doi.org/10.1021/es102951k, 2011a.

Ng, N. L., Herndon, S. C., Trimborn, A., Canagaratna, M. R., Croteau, P. L., Onasch, T. B., Sueper, D., Worsnop, D. R., Zhang, Q., Sun, Y. L., and Jayne, J. T.: An Aerosol Chemical Speciation 
Monitor (ACSM) for routine monitoring of the composition and mass concentrations of ambient aerosol, Aerosol Sci. Tech., 45, 770-784, 2011b.

Ots, R., Vieno, M., Allan, J. D., Reis, S., Nemitz, E., Young, D. E., Coe, H., Di Marco, C., Detournay, A., Mackenzie, I. A., Green, D. C., and Heal, M. R.: Model simulations of cooking organic aerosol (COA) over the UK using estimates of emissions based on measurements at two sites in London, Atmos. Chem. Phys., 16, 13773-13789, https://doi.org/10.5194/acp-16-137732016, 2016.

Paatero, P.: The multilinear engine - A table-driven, least squares program for solving multilinear problems, including the n-way parallel factor analysis model, J. Comput. Graph. Stat., 8, 854$888,1999$.

Parworth, C., Fast, J., Mei, F., Shippert, T., Sivaraman, C., Tilp, A., Watson, T., and Zhang, Q.: Long-term Measurements of Submicrometer Aerosol Chemistry at the Southern Great Plains (SGP) Using an Aerosol Chemical Speciation Monitor (ACSM), Atmos. Environ., 106, 43-55, 2015.

Petit, J.-E., Favez, O., Sciare, J., Crenn, V., Sarda-Estève, R., Bonnaire, N., Mocnik, G., Dupont, J.-C., Haeffelin, M., and LeozGarziandia, E.: Two years of near real-time chemical composition of submicron aerosols in the region of Paris using an Aerosol Chemical Speciation Monitor (ACSM) and a multiwavelength Aethalometer, Atmos. Chem. Phys., 15, 2985-3005, https://doi.org/10.5194/acp-15-2985-2015, 2015.

Polissar, A. V., Hopke, P. K., Paatero, P., Kaufman, Y. J., Hall, D. K., Bodhaine, B. A., Dutton, E. G., and Harris, J. M.: The aerosol at Barrow, Alaska: long-term trends and source locations, Atmos. Environ., 33, 2441-2458, 1999.

Rattanavaraha, W., Canagaratna, M. R., Budisulistiorini, S. H., Croteau, P. L., Baumann, K., Canonaco, F., Prevot, A. S. H., Edgerton, E. S., Zhang, Z., Jayne, J. T., Worsnop, D. R., Gold, A., Shaw, S. L., and Surratt, J. D.: Source apportionment of submicron organic aerosol collected from Atlanta, Georgia, during 2014-2015 using the aerosol chemical speciation monitor (ACSM), Atmos. Environ., 167, 389-402, 2017.

Ripoll, A., Minguillón, M. C., Pey, J., Jimenez, J. L., Day, D. A., Sosedova, Y., Canonaco, F., Prévôt, A. S. H., Querol, $\mathrm{X}$., and Alastuey, A.: Long-term real-time chemical characterization of submicron aerosols at Montsec (southern Pyrenees, $1570 \mathrm{~m}$ a.s.l.), Atmos. Chem. Phys., 15, 2935-2951, https://doi.org/10.5194/acp-15-2935-2015, 2015.

Schlag, P., Kiendler-Scharr, A., Blom, M. J., Canonaco, F., Henzing, J. S., Moerman, M., Prévôt, A. S. H., and Holzinger, R.: Aerosol source apportionment from 1-year measurements at the CESAR tower in Cabauw, the Netherlands, Atmos. Chem. Phys., 16, 8831-8847, 10.5194/acp-16-8831-2016, 2016.

Shrivastava, M., Fast, J., Easter, R., Gustafson Jr, W. I., Zaveri, R. A., Jimenez, J. L., Saide, P., and Hodzic, A.: Modeling organic aerosols in a megacity: comparison of simple and complex representations of the volatility basis set approach, Atmos. Chem. Phys., 11, 6639-6662, https://doi.org/10.5194/acp11-6639-2011, 2011.

Shrivastava, M., Cappa, C. D., Fan, J., Goldstein, A. H., Guenther, A. B., Jimenez, J. L., Kuang, C., Laskin, A., Martin, S. T., Ng, N. L., Petaja, T., Pierce, J. R., Rasch, P. J., Roldin, P., Seinfeld, J. H., Shilling, J., Smith, J. N., Thornton, J. A., Volkamer, R., Wang, J., Worsnop, D. R., Zaveri, R. A., Zelenyuk, A., and Zhang, Q.: Re- cent advances in understanding secondary organic aerosol: implications for global climate forcing, Rev. Geophys., 55, 509-559, 10.1002/2016RG000540, 2017.

Sun, J., Zhang, Q., Canagaratna, M. R., Zhang, Y., Ng, N. L., Sun, Y., Jayne, J. T., Zhang, X., Zhang, X., and Worsnop, D. R.: Highly time- and size-resolved characterization of submicron aerosol particles in Beijing using an Aerodyne Aerosol Mass Spectrometer, Atmos. Environ., 44, 131-140, 2010.

Sun, J., Huang, L., Liao, H., Li, J., and Hu, J.: Impacts of Regional Transport on Particulate Matter Pollution in China: a Review of Methods and Results, Current Pollution Reports, 3, 182-191, https://doi.org/10.1007/s40726-017-0065-5, 2017.

Sun, Y., Chen, C., Zhang, Y., Xu, W., Zhou, L., Cheng, X., Zheng, H., Ji, D., Li, J., Tang, X., Fu, P., and Wang, Z.: Rapid formation and evolution of an extreme haze episode in Northern China during winter 2015, Sci. Rep., 6, 27151, https://doi.org/10.1038/srep27151, 2016a.

Sun, Y., Du, W., Fu, P., Wang, Q., Li, J., Ge, X., Zhang, Q., Zhu, C., Ren, L., Xu, W., Zhao, J., Han, T., Worsnop, D. R., and Wang, Z.: Primary and secondary aerosols in Beijing in winter: sources, variations and processes, Atmos. Chem. Phys., 16, 8309-8329, https://doi.org/10.5194/acp-16-8309-2016, $2016 \mathrm{~b}$.

Sun, Y., Jiang, Q., Xu, Y., Ma, Y., Zhang, Y., Liu, X., Li, W., Wang, F., Li, J., Wang, P., and Li, Z.: Aerosol Characterization over the North China Plain: Haze Life Cycle and Biomass Burning Impacts in Summer, J. Geophys. Res., 121, 2508-2521, https://doi.org/10.1002/2015JD024261, 2016c.

Sun, Y. L., Zhang, Q., Schwab, J. J., Chen, W. N., Bae, M. S., Lin, Y. C., Hung, H. M., and Demerjian, K. L.: A case study of aerosol processing and evolution in summer in New York City, Atmos. Chem. Phys., 11, 12737-12750, https://doi.org/10.5194/acp-1112737-2011, 2011a.

Sun, Y.-L., Zhang, Q., Schwab, J. J., Demerjian, K. L., Chen, W.N., Bae, M.-S., Hung, H.-M., Hogrefe, O., Frank, B., Rattigan, O. V., and Lin, Y.-C.: Characterization of the sources and processes of organic and inorganic aerosols in New York city with a high-resolution time-of-flight aerosol mass apectrometer, Atmos. Chem. Phys., 11, 1581-1602, https://doi.org/10.5194/acp11-1581-2011, $2011 \mathrm{~b}$.

Sun, Y. L., Wang, Z., Dong, H., Yang, T., Li, J., Pan, X., Chen, P., and Jayne, J. T.: Characterization of summer organic and inorganic aerosols in Beijing, China with an Aerosol Chemical Speciation Monitor, Atmos. Environ., 51, 250-259, https://doi.org/10.1016/j.atmosenv.2012.01.013, 2012.

Sun, Y. L., Wang, Z., Fu, P., Jiang, Q., Yang, T., Li, J., and Ge, $\mathrm{X}$.: The impact of relative humidity on aerosol composition and evolution processes during wintertime in Beijing, China, Atmos. Environ., 77, 927-934, 2013a.

Sun, Y. L., Wang, Z. F., Fu, P. Q., Yang, T., Jiang, Q., Dong, H. B., Li, J., and Jia, J. J.: Aerosol composition, sources and processes during wintertime in Beijing, China, Atmos. Chem. Phys., 13, 4577-4592, https://doi.org/10.5194/acp-13-4577-2013, 2013b.

Sun, Y. L., Jiang, Q., Wang, Z., Fu, P., Li, J., Yang, T., and Yin, Y.: Investigation of the sources and evolution processes of severe haze pollution in Beijing in January 2013, J. Geophys. Res., 119, 4380-4398, https://doi.org/10.1002/2014JD021641, 2014.

Sun, Y. L., Wang, Z. F., Du, W., Zhang, Q., Wang, Q. Q., Fu, P. Q., Pan, X. L., Li, J., Jayne, J., and Worsnop, D. R.: Longterm real-time measurements of aerosol particle composition 
in Beijing, China: seasonal variations, meteorological effects, and source analysis, Atmos. Chem. Phys., 15, 10149-10165, https://doi.org/10.5194/acp-15-10149-2015, 2015.

Tang, G., Zhang, J., Zhu, X., Song, T., Münkel, C., Hu, B., Schäfer, K., Liu, Z., Zhang, J., Wang, L., Xin, J., Suppan, P., and Wang, Y.: Mixing layer height and its implications for air pollution over Beijing, China, Atmos. Chem. Phys., 16, 2459-2475, https://doi.org/10.5194/acp-16-2459-2016, 2016.

Ulbrich, I. M., Canagaratna, M. R., Zhang, Q., Worsnop, D. R., and Jimenez, J. L.: Interpretation of organic components from Positive Matrix Factorization of aerosol mass spectrometric data, Atmos. Chem. Phys., 9, 2891-2918, https://doi.org/10.5194/acp-92891-2009, 2009.

Wang, H., Lu, K., Chen, X., Zhu, Q., Chen, Q., Guo, S., Jiang, M., Li, X., Shang, D., Tan, Z., Wu, Y., Wu, Z., Zou, Q., Zheng, Y., Zeng, L., Zhu, T., Hu, M., and Zhang, Y.: High $\mathrm{N}_{2} \mathrm{O}_{5}$ Concentrations Observed in Urban Beijing: Implications of a Large Nitrate Formation Pathway, Environ. Sci. Tech. Lett., 4, 416-420, https://doi.org/10.1021/acs.estlett.7b00341, 2017.

Wang, Q., Sun, Y., Jiang, Q., Du, W., Sun, C., Fu, P., and Wang, Z.: Chemical composition of aerosol particles and light extinction apportionment before and during the heating season in Beijing, China, J. Geophys. Res., 120, 12708-12722, 10.1002/2015JD023871, 2015.

Wang, Y., Yao, L., Wang, L., Liu, Z., Ji, D., Tang, G., Zhang, J., Sun, Y., Hu, B., and Xin, J.: Mechanism for the formation of the January 2013 heavy haze pollution episode over central and eastern China, Sci. China Earth Sci., 57, 14-25, https://doi.org/10.1007/s11430-013-4773-4, 2014.

Zhang, H., Li, J., Ying, Q., Yu, J. Z., Wu, D., Cheng, Y., He, K., and Jiang, J.: Source apportionment of $\mathrm{PM}_{2.5}$ nitrate and sulfate in China using a source-oriented chemical transport model, Atmos. Environ., 62, 228-242, https://doi.org/10.1016/j.atmosenv.2012.08.014, 2012.

Zhang, Q., Alfarra, M. R., Worsnop, D. R., Allan, J. D., Coe, H., Canagaratna, M. R., and Jimenez, J. L.: Deconvolution and quantification of hydrocarbon-like and oxygenated organic aerosols based on aerosol mass spectrometry, Environ. Sci. Technol., 39, 4938-4952, https://doi.org/10.1021/es0485681, 2005.

Zhang, Q., Jimenez, J. L., Canagaratna, M. R., Allan, J. D., Coe, H., Ulbrich, I., Alfarra, M. R., Takami, A., Middlebrook, A. M., Sun, Y. L., Dzepina, K., Dunlea, E., Docherty, K., DeCarlo, P. F., Salcedo, D., Onasch, T., Jayne, J. T., Miyoshi, T., Shimono, A., Hatakeyama, S., Takegawa, N., Kondo, Y., Schneider, J., Drewnick, F., Weimer, S., Demerjian, K., Williams, P., Bower, K., Bahreini, R., Cottrell, L., Griffin, R. J., Rautiainen, J., Sun, J. Y., Zhang, Y. M., and Worsnop, D. R.: Ubiquity and dominance of oxygenated species in organic aerosols in anthropogenicallyinfluenced northern hemisphere mid-latitudes, Geophys. Res. Lett., 34, L13801, https://doi.org/10.1029/2007GL029979, 2007.
Zhang, Q., Jimenez, J., Canagaratna, M., Ulbrich, I., Ng, N., Worsnop, D., and Sun, Y.: Understanding atmospheric organic aerosols via factor analysis of aerosol mass spectrometry: a review, Anal. Bioanal. Chem., 401, 3045-3067, https://doi.org/10.1007/s00216-011-5355-y, 2011.

Zhang, Y., Sun, J., Zhang, X., Shen, X., Wang, T., and Qin, M.: Seasonal characterization of components and size distributions for submicron aerosols in Beijing, Sci. China Earth Sci., 56, 890900, https://doi.org/10.1007/s11430-012-4515-z, 2013.

Zhang, Y., Sun, Y., Du, W., Wang, Q., Chen, C., Han, T., Lin, J., Zhao, J., Xu, W., Gao, J., Li, J., Fu, P., Wang, Z., and Han, Y.: Response of aerosol composition to different emission scenarios in Beijing, China, Sci. Total Environ., 571, 902-908, 2016.

Zhang, Y. J., Tang, L. L., Wang, Z., Yu, H. X., Sun, Y. L., Liu, D., Qin, W., Canonaco, F., Prévôt, A. S. H., Zhang, H. L., and Zhou, H. C.: Insights into characteristics, sources, and evolution of submicron aerosols during harvest seasons in the Yangtze River delta region, China, Atmos. Chem. Phys., 15, 1331-1349, https://doi.org/10.5194/acp-15-1331-2015, 2015.

Zhao, J., Du, W., Zhang, Y., Wang, Q., Chen, C., Xu, W., Han, T., Wang, Y., Fu, P., Wang, Z., Li, Z., and Sun, Y.: Insights into aerosol chemistry during the 2015 China Victory Day parade: results from simultaneous measurements at ground level and $260 \mathrm{~m}$ in Beijing, Atmos. Chem. Phys., 17, 3215-3232, https://doi.org/10.5194/acp-17-3215-2017, 2017.

Zhao, X. J., Zhao, P. S., Xu, J., Meng,, W., Pu, W. W., Dong, F., He, D., and Shi, Q. F.: Analysis of a winter regional haze event and its formation mechanism in the North China Plain, Atmos. Chem. Phys., 13, 5685-5696, https://doi.org/10.5194/acp13-5685-2013, 2013.

Zheng, G., Duan, F., Ma, Y., Zhang, Q., Huang, T., Kimoto, T., Cheng, Y., Su, H., and He, K.: Episode-Based Evolution Pattern Analysis of Haze Pollution: Method Development and Results from Beijing, China, Environ. Sci. Technol., 50, 4632-4641, https://doi.org/10.1021/acs.est.5b05593, 2016.

Zhou, S., Collier, S., Jaffe, D. A., Briggs, N. L., Hee, J., Sedlacek III, A. J., Kleinman, L., Onasch, T. B., and Zhang, Q.: Regional influence of wildfires on aerosol chemistry in the western US and insights into atmospheric aging of biomass burning organic aerosol, Atmos. Chem. Phys., 17, 2477-2493, https://doi.org/10.5194/acp-17-2477-2017, 2017. 